\title{
Metabolic responses of clam Ruditapes philippinarum exposed to its pathogen Vibrio tapetis in relation to diet
}

\author{
Richard Gaëlle ${ }^{1, *}$, Guérard Fabienne ${ }^{1}$, Corporeau Charlotte ${ }^{2}$, Lambert Christophe ${ }^{1}$, \\ Paillard Christine ${ }^{1}$, Pernet Fabrice ${ }^{2}$
}

${ }^{1}$ UMR 6539 CNRS UBO IRD IFREMER, LEMAR - IUEM - UBO, Institut Universitaire Européen de la Mer, Université de Bretagne Occidentale, Technopôle Brest-Iroise - Rue Dumont d'Urville, 29280 Plouzané, France

${ }^{2}$ Ifremer, UMR 6539 LEMAR (CNRS/UBO/IRD/Ifremer), Technopôle Brest-Iroise CS 10070, 29280 Plouzané, France

* Corresponding author : Gaëlle Richard, email address : gaelle.richard@univ-brest.fr

\begin{abstract}
:
We investigated the effect of brown ring disease (BRD) ${ }^{1}$ development and algal diet on energy reserves and activity of enzymes related to energy metabolism, antioxidant system and immunity in Manila clam, Ruditapes philippinarum. We found that algal diet did not impact the metabolic response of clams exposed to Vibrio tapetis. At two days post-injection (dpi), activities of superoxide dismutase and glutathione peroxidase (GPx) decreased whereas activities of nitric oxide synthase (iNOS) and catalase increased in infected clams, although no clinical signs were visible (BRD-). At $7 \mathrm{dpi}$, activities of several antioxidant and immune-related enzymes were markedly increased in BRD-likely indicating an efficient reactive oxygen species (ROS) scavenging compared to animals which developed clinical signs of BRD (BRD+). Therefore, resistance to BRD clinical signs appearance was associated with higher detoxification of ROS and enhancement of immune response. This study provides new biochemical indicators of disease resistance and a more comprehensive view of the global antioxidant response of clam to BRD development.
\end{abstract}

\section{Highlights}

- Brown ring disease affects antioxidant and immune response of clams. Resistance to the clam disease is associated with higher antioxidant activities. New bio-indicators of resistance to brown ring disease development are provided.

Keywords: Antioxidant enzymes, immunity, energetic metabolism, Ruditapes philippinarum, Vibrio tapetis 


\section{List of abbreviations}

- $\quad$ BRD, brown ring diseases;

- dpi, days post injection;

- ROS, reactive oxygen species;

- RNS, reactive nitrogen species;

- $\mathrm{t}-\mathrm{SOD}$, total superoxide dismutase;

- $\mathrm{Cu} / \mathrm{Zn}-\mathrm{SOD}, \mathrm{Cu} / \mathrm{Zn}$ superoxide dismutase;

- Mn-SOD, Mn superoxide dismutase;

- CAT, catalase;

- $\mathrm{t}-\mathrm{GPx}$, total glutathion peroxidase;

- Se-GPx, selenium-dependant glutathione peroxidase;

- GR, glutathion reductase;

- GST, glutathione-S-transferase;

- TrxP, thioredoxin peroxidase;

- TrxR, thioredoxin reductase;

- iNOS, inducible nitric oxide synthase;

- $\quad$ PO, phenoloxidase;

- HK, hexokinase;

- PK, pyruvate kinase;

- CS, citrate synthase

\section{Introduction}

The bacteria Vibrio tapetis is the causative agent of Brown Ring Disease (BRD) which has affected the Manila clam Ruditapes philippinarum worldwide since the late 80's ( Paillard and Maes, 1994). The main clinical sign of BRD is a brown organic deposit called conchiolin on the inner shell of the clam. This defense response of the mantle is called "nacrezation" and involves the deposition of conchiolin to enclose the pathogen followed by the deposition of new calcified layers which may lead to shell repair (Paillard and Maes, 1995; Trinkler et al., 2010). When these defense responses are not sufficient, lesions occur and the pathogen invades the host leading to septicaemia and death (Allam et al., 2002).

Bacterial exposure can induce important alterations in the energy reserves of bivalves and consequently on their metabolism. For instance, clams infected with $V$. tapetis exhibit glycogen reserve depletion, weight loss and lower condition indices (Goulletquer and Université de Bretagne Occidentale, 1989; Plana, 1995; Plana et al., 1996). Also, energetic status of the host plays a major role in the outcome (death or recovery) of a bacterial infection in bivalves (Paillard, 2004; Flye-Sainte-Marie et al., 2007; Genard et al., 2013). For instance, oyster Crassostrea virginica larvae exposed to Vibrio corallilyticus show a marked decline in food intake which coincides with lower triglyceride and protein content, the two main energetic reserves in bivalve larvae ( Genard et al., 2013).

The invertebrate immune system is non-adaptive or innate and incorporates cellular and humoral components (Ellis et al., 2011). The main cellular defense mechanism relies on phagocytosis by immunocompetent cells known as haemocytes, and it consists of several steps including recognition, chemotaxis, attachment, incorporation and destruction through 
the production of reactive oxygen species (ROS) and reactive nitrogen species (RNS) (Pipe and Coles, 1995; Chu, 2000; Soudant et al., 2013; Donaghy et al., 2015).

The internal destruction of pathogenic agents in bivalves relies on an increased production of ROS and RNS that are toxic to invaders (Donaghy et al., 2015). Accumulation of ROS and RNS can result in oxidative stress in the host (Lesser, 2006), which is normally prevented by antioxidant enzymes (Sies, 1993; Hermes-Lima, 2004). Superoxide dismutase (SOD) transforms the superoxide anion $\left(\mathrm{O}_{2}{ }^{\circ-}\right)$ into hydrogen peroxide $\left(\mathrm{H}_{2} \mathrm{O}_{2}\right)$ (Manduzio et al., 2005). $\mathrm{H}_{2} \mathrm{O}_{2}$ is decomposed into $\mathrm{H}_{2} \mathrm{O}$ and $\mathrm{O}_{2}$ by catalase (CAT) or by glutathione peroxidases (GPx) and thioredoxin peroxidase (TrxP) when $\mathrm{H}_{2} \mathrm{O}_{2}$ and organic peroxides concentration are low (Hermes-Lima, 2004; Manduzio et al., 2005). Activities of GPx and TrxP depend on oxidation states of glutathione and thioredoxin ( $\operatorname{Tr} x)$ respectively, which are controlled by glutathione reductase (GR) and thioredoxin reductase (TrxR) (Powis and Montfort, 2001). Finally, glutathione-S-transferase (GST) is an antioxidant enzyme involved in xenobiotics detoxification and scavenging of lipid peroxides (Hermes-Lima, 2004; Manduzio et al., 2005). These reactions are summarized in Figure 1.

Many studies have investigated the effect of bacterial infection on gene expression of antioxidant enzymes in bivalves, but very few consider effects on enzymatic activity. Expression of RpSOD, RpGST and RpTrx increased in gills and haemocytes of R. philippinarum during a short-term exposure to $V$. tapetis (Revathy et al., 2012a, 2012b; Umasuthan et al., 2012a, 2012b, 2012c). Although gene expression of antioxidant enzymes is sometimes correlated with their activity (Genard et al., 2013), this is not always the case (Chen et al., 2002; Canesi et al., 2010; Béguel et al., 2013). Activities of SOD, CAT and GST increased in response to bacterial infection whereas other enzymes were not influenced or not examined (Canesi et al., 2010; Genard et al., 2013; Le Bris et al., 2015).

In addition to antioxidant enzymes, other immune-related enzymes are involved in pathogen destruction in bivalves. Inducible nitric oxide synthase (iNOS) produces nitric oxide (NO), a RNS which putatively leads to the formation of peroxynitrite, nitrosothiols and other nitrogen derivative in cells that are harmful to pathogens (Hausladen and Stamler, 1999; Donaghy et al., 2015). Additionally, in vitro production of nitrites, which are NO breakdown products, is correlated with the concentration of $V$. tapetis in hemolymph and extrapallial 
fluids of R. philippinarum (Jeffroy and Paillard, 2011). To our knowledge, iNOS activity has never been investigated in bivalves during exposure to pathogen.

Finally, phenoloxidases (PO) have a key role in innate immunity in bivalves by activating the melanization cascade which leads to the production of melanin and its derivatives (Aladaileh et al., 2007; Cerenius et al., 2008). These compounds exhibit fungistatic, bacteriostatic and antiviral properties (Cerenius et al., 2008; Luna-Acosta et al., 2011). PO is a particularly important aspect of BRD as it contributes to the conchiolin deposit formation (Paillard et al., 1994). Bivalves exposed to pathogens generally exhibit higher PO activity than control animals (Butt and Raftos, 2008; Le Bris et al., 2015; Richard et al., 2015).

In bivalves, haemocyte functions are influenced by dietary fatty acids (Delaporte et al., 2003, 2006, 2007; Dudognon et al., 2014). We investigated the effect of diet on the dynamics of BRD in $R$. philippinarum in relation to reproductive status in another paper (Richard, 2015). We showed that disease prevalence and intensity as well as haemocyte parameters were not influenced by diet. However, sexual maturity enhanced BRD intensity, likely reflecting an energetic trade-off between reproduction and immunity.

Objectives of the present study were to investigate the effect of BRD development and algal diet quality during a V. tapetis exposure on: (1) lipid, protein and carbohydrate content, and activity of enzymes related to energy metabolism such as hexokinase (HK), pyruvate kinase (PK) and citrate synthase (CS); (2) activity of the antioxidant enzymes SOD, CAT, GPx, (GR), (TrxR), and GST, and (3) activity of two immune-related enzymes, iNOS and PO. In this study, mantle of clams was individually sampled and pooled for biochemical analysis according to diet, injection, tank replicate and BRD status at each time postinjection (2, 7 and $30 \mathrm{dpi})$. The originality of our work is that we clearly describe the metabolic response of clams exposed to $V$. tapetis as a function of disease development. In particular, we characterize the metabolic response associated with the appearance of disease clinical signs, thereby providing new biochemical indicators of disease resistance. Also, we obtain a more comprehensive view of the global antioxidant response of clam to the disease than previous studies which have generally focused only on SOD and CAT. 


\section{Material and methods}

\subsection{Experimental design}

Animals and experimental design are fully described in a companion paper (See Richard, 2015). Briefly, clams were acclimated for four weeks with either Isochrysis aff. galbana, clone Tahitian (T-Iso) or Chaetoceros calcitrans, two algal species exhibiting differences in their biochemical compositions. Then, clams were injected in extrapallial cavity with $100 \mu \mathrm{L}$ of CECT4600 ${ }^{\top} V$. tapetis suspension $\left(10^{7} \mathrm{UFC} \cdot \mathrm{mL}^{-1}\right)$ or $100 \mu \mathrm{L}$ of filtered-sea water (FSW) and further monitored for 30 days. Clam shells were collected at 2, 7 and 30 dpi to assess disease prevalence intensity. Additionally, sex and sexual maturity were evaluated and tested as internal parameters influencing BRD development.

Algal cultures of $C$. calcitrans and T-Iso were collected three times during the course of the conditioning period for fatty acid composition analyses. Briefly, algae were filtered on pre-ignited GF/F filters, placed into $6 \mathrm{~mL}$ vials containing $3 \mathrm{~mL}$ of chloroform:methanol (2:1, $\mathrm{v}: \mathrm{v})$ and stored at $-20^{\circ} \mathrm{C}$ until analyses.

Clams injected with $V$. tapetis and control animals injected with FSW collected at 2, 7 and $30 \mathrm{dpi}$ were carefully dissected on ice. Whole clam mantle (Ma) and digestive gland (DG) were flash-frozen in liquid nitrogen and stored at $-80^{\circ} \mathrm{C}$. Samples were individually powdered using a Retsch MM 400 under liquid nitrogen. Then, an equal amount of powder originating from the same condition of diet $\times$ injection treatment $\times$ BRD status $\times$ tank for each organ at each sampling time were pooled together to obtain enough biological materials for biochemical analysis, such that each individual had the same weight contribution to the pool (Table 1). Clams injected with V. tapetis were classified as either BRD- (no clinical sign of infection) or BRD+ (visible brown ring). For the control, visibly healthy clams were selected. Only mature male were analyzed because the sex ratio was in favor of males (1.5:1.0) and most of them were mature. Each pool consisted of 2 to 4 individuals per condition. The number of replicates was therefore not homogenous because it depends on clinical signs development and reproduction stages occurrence. 
Ma were analyzed for carbohydrate and protein contents, and immunity-, antioxidant- and metabolism-related enzyme activities at 2, 7 and $30 \mathrm{dpi}$. Immune related enzymes were analyzed through iNOS and PO activities, antioxidant enzymes through SOD,

142 CAT, GPx, TrxR, GR, GST activities and metabolism-related enzymes through citrate synthase 143 (CS), HK and pyruvate kinase (PK) activities.

Additionally, Ma samples were analyzed for fatty acid composition of polar lipids at 7

145 dpi to evaluate peroxidation index in membrane lipids. Fatty acids of neutral lipids were analyzed in DG at 2 dpi to verify that diet effectively influenced the biochemical composition of clams. Indeed, fatty acids composition of neutral lipids generally mirrors that of the food (Dalsgaard et al., 2003). For these analyses, powder of DG and Ma was transferred into $6 \mathrm{~mL}$ vials containing chloroform:methanol mixture $(2: 1, \mathrm{v}: \mathrm{v})$ and stored at $-20^{\circ} \mathrm{C}$ until analyses.

\subsection{Biochemical analyses}

\subsubsection{Fatty acid}

Fatty acid composition was analyzed in total lipid of algae, in neutral lipids of clam DG at $2 \mathrm{dpi}$ and in polar lipids of clam Ma at $7 \mathrm{dpi}$. Neutral and polar lipids were separated using a silica gel micro-column as described in Marty et al. (Marty et al., 1992). Briefly, aliquots of samples were evaporated until dry and lipid extracts were recovered after three chloroform:methanol $(98: 2, \mathrm{v} / \mathrm{v})$ washings. The resulting extracts were placed on top of a silica gel micro-column. Columns were washed with $10 \mathrm{~mL}$ chloroform:methanol $(98: 2, \mathrm{v} / \mathrm{v})$ to elute neutral lipids followed by $15 \mathrm{~mL}$ of methanol to elute polar lipids. Then, a known amount of tricosaenoic acid (23:0) was added as an internal standard in both fractions. Each lipid fraction was transesterified using 10\% boron-trifluoride methanol (Metcalfe and Schmitz, 1961) and analyzed in a gas chromatograph with an on-column injector, DB-Wax capillary column and a flame ionization detector. Fatty acids were then identified by comparison of retention times with standards and checked using a non-polar column. 
Carbohydrates contents were analyzed using the method of Dubois et al. (Dubois et

168

169

170

171

172

173

174

175

176

177

178

179

180

181

182

183

184

185

186

187

188

189

190

191

192 al., 1956). Carbohydrates were extracted from $\mathrm{Ma}$ in a $10 \mathrm{mM}$ phosphate buffered saline (PBS) containing EDTA $(1 \mathrm{mM})$ and Triton $^{\circledR} \mathrm{X}-100(0.1 \%)$ at the ratio of $50 \mathrm{mg}$ of powder in $250 \mu \mathrm{L}$ of buffer. Standard solution of $0.4 \mathrm{mg} / \mathrm{mL}$ glucose was serially diluted in PBS (ranging from 0.4 to $0.01 \mathrm{mg} / \mathrm{mL}$ ) to provide a standard curve for the assay. Then, $500 \mu \mathrm{L}$ of $5 \%$ phenol solution was added to $250 \mu \mathrm{L}$ of samples and standard solutions. The resulting solution was allowed to incubate during $40 \mathrm{~min}$ in the dark. The colorimetric reaction was initiated by addition of $2.5 \mathrm{~mL} \mathrm{H}_{2} \mathrm{SO}_{4}$. After $40 \mathrm{~min}$, all solutions were placed in cuvettes and absorbance was read at 490 and $600 \mathrm{~nm}$ on an Uvikon 941 (Kontron instruments). Carbohydrate content was calculated using a standard curve and the following expression:

$$
O D_{s}=O D_{s, 490}-1.5 \times\left(O D_{s, 600}-0.003\right)
$$

Where $O D_{S}$ is the sample optical density of the sample; $O D_{S, 490}$ is the sample optical density at $490 \mathrm{~nm}$; and $O D_{s, 600}$ is the sample optical density at $600 \mathrm{~nm}$. Results are expressed as $\mathrm{mg}$ per g wet weight.

\subsubsection{Protein}

For each sample, $50 \mathrm{mg}$ of powder was homogenized in $250 \mu \mathrm{L}$ of extraction buffer using an Ultra-Turrax ${ }^{\circledR}$. Two extraction buffers were tested and used for enzymatic assays in order to avoid interactions with assays buffers and therefore with enzymatic activities. The extraction buffer used prior to SOD, PO, PK, HK, CS, GPx-t and GPx-Se enzymatic assays consisted in $\mathrm{NaCl}(150 \mathrm{mM})$, Tris $\mathrm{HCl}(10 \mathrm{mM})$, EDTA (1mM), EGTA (1mM), phosphatase inhibitor cocktail II (1\%; Sigma-Aldrich), Triton $^{\circledR}$ X-100 (1\%; Sigma-Aldrich), CA-630 |gepal ${ }^{\circledR}$ (0.5\%; Sigma-Aldrich) and 1 tablet $/ 25 \mathrm{~mL}$ of complete EDTA free protease inhibitor cocktail (Roche) (Corporeau et al., 2012). The extraction buffer used prior to CAT, GR, GST, NOS and TrXR enzymatic assays consisted in Phosphate buffered saline (PBS 10mM; Sigma-Aldrich), EDTA (1mM) and Triton ${ }^{\circledR}$ X-100 (0.1\%; Sigma-Aldrich). After homogenization, samples were centrifuged at $1000 \mathrm{~g}$ for 10 minutes at $4^{\circ} \mathrm{C}$ to eliminate the lipid fraction of the samples and then centrifuged at $10000 \mathrm{~g}$ for 45 minutes at $4^{\circ} \mathrm{C}$. The resulting supernatants were split 
193 194

195 196

197 198

199

200

201

202

203

204

205

206

207

208

209

210

211

212

213

214

215

216

217

218

219

220

among 9-10 separate microtubes for subsequent protein and enzyme assays, and stored at $80^{\circ} \mathrm{C}$.

Protein concentrations were evaluated in samples previously homogenized with each buffer by the Bradford method using the Biorad Protein Assay Dye Reagent Concentrate (BioRad France) and Bovine Serum Albumin (BSA) as protein standard. Results are expressed as $\mathrm{mg}$ per g wet weight.

\subsubsection{Enzyme}

Activities were measured using 96-well microplates (Greiner 96-F-bottom) and Synergy HT (Bio-Tek), except for catalase activity which was measured using quartz cuvettes and Uvikon 941 (Kontron instruments).

\section{Energy-related enzymes}

Citrate Synthase (CS, EC 2.3.3.8) was assayed by recording the conversion of DTNB into TNB (Childress and Somero, 1979). Briefly, $20 \mu \mathrm{L}$ of protein supernatant were added to triplicate wells as well as serial dilutions of commercial CS from porcine heart (Sigma-Aldrich France) (ranging from 5 to $100 \mathrm{mU} / \mathrm{mL}$ ), which was used as a standard for this reaction. One hundred and sixty $\mu \mathrm{L}$ of assay buffer $(0.25 \mathrm{mM}$ acetyl-CoA, $0.125 \mathrm{mM}$ DTNB and $100 \mathrm{mM}$ Tris- $\mathrm{HCl}$ ) were added to wells and the reaction was initiated by addition of $20 \mu \mathrm{L}$ of $5 \mathrm{mM}$ oxaloacetate. In blank wells, samples were replaced by extraction buffer. Absorbance was monitored for $10 \mathrm{~min}$ at $412 \mathrm{~nm}$. Results are expressed in $\mathrm{U} / \mathrm{mg}$ protein; one $\mathrm{U}$ being defined as the amount of enzyme catalyzing $1 \mu$ mole of TNB per $\min \left(\varepsilon_{\mathrm{TNB}, 412}=13.6 \mathrm{mM}^{-1} \cdot \mathrm{cm}^{-1}\right)$.

Pyruvate Kinase (PK, EC 2.7.1.40) and hexokinase (HK, EC 2.7.1.1) activities were measured using the protocol developed by Greenway and Storey (Greenway and Storey, 1999). Twenty $\mu \mathrm{L}$ of protein supernatant were loaded in triplicate wells and $20 \mu \mathrm{L}$ of extraction buffer was used for the blank wells. For PK, $180 \mu \mathrm{L}$ of assay buffer $(100 \mathrm{mM}$ imidazole- $\mathrm{HCl}, 50 \mathrm{mM} \mathrm{KCl}, 5 \mathrm{mM} \mathrm{MgCl}$, $10 \mathrm{mM}$ phosphoenolpyruvate, $2 \mathrm{mM} \mathrm{NADH}, 0.2 \%$ $(\mathrm{v} / \mathrm{v})$ rotenone saturated ethanol and $1 \mathrm{U} / \mathrm{mL}$ lactate dehydrogenase) were added to the wells and the reaction was monitored for $15 \mathrm{~min}$ at $340 \mathrm{~nm}$. For HK, the reaction was initiated by addition of $200 \mu \mathrm{L}$ of assay buffer (100 mM Tris, $1 \mathrm{mM}$ EDTA, $2 \mathrm{mM} \mathrm{MgCl}, 5 \mathrm{mM}$ 
221 glucose, $1 \mathrm{mM}$ ATP, $0.2 \mathrm{mM} \mathrm{NADP}^{+}$and $1 \mathrm{U} / \mathrm{mL}$ Glucose-6-Phosphate Dehydrogenase) and reaction kinetics was followed during $15 \mathrm{~min}$ at $340 \mathrm{~nm}$. Results are expressed as $\mathrm{U} / \mathrm{mg}$ 223 protein; one $U$ being defined as the amount of enzyme oxidizing $1 \mu$ mole of NADH or NADP ${ }^{+}$ 224 (using $\varepsilon_{\mathrm{NADH}}$ or NADP+, $340=6.22 \mathrm{mM}^{-1} \cdot \mathrm{cm}^{-1}$ ).

\section{Antioxidant enzymes}

Total Superoxide Dismutase (t-SOD, EC 1.15.1.1) activity was measured using the SOD Assay Kit (Sigma-Aldrich, France) following a modified procedure (Richard et al., 2015). Briefly, the inhibition of the xanthine/xanthine oxidase complex was followed recording the absorbance at $440 \mathrm{~nm}$ after 20 minutes of incubation at $25^{\circ} \mathrm{C}$. Additionally, mitochondrial SOD (Mn SOD) activity was assayed by addition of potassium cyanide, which was found to inhibit specifically cytosolic SOD (Cu-Zn SOD) at concentrations above $2 \mathrm{mM}$ in Mytilus edulis (Manduzio et al., 2003). In a preliminary assay, we tested a range of potassium cyanide concentrations $(0-10 \mathrm{mM})$ and the $5 \mathrm{mM}$ concentration was selected for the Mn SOD assay in clams. Mn SOD activity and subsequently Cu-Zn SOD activity (calculated as the activity difference between t-SOD and Mn SOD) were assayed using the same kit and adding $5 \mathrm{mM}$ potassium cyanide to the assay buffer. All SOD activities are expressed in $\mathrm{U} / \mathrm{mg}$ total protein where one unit is the amount of enzyme necessary for inhibiting by $50 \%$ the xanthine/xanthine oxidase complex.

Catalase (CAT, EC 1.11.1.6) activity was assessed following Aebi (Aebi, 1984). Briefly, $8 \mu \mathrm{L}$ of protein supernatant were added to $792 \mu \mathrm{L}$ of hydrogen peroxide solution $(10 \mathrm{mM})$ to initiate the reaction. Absorbance was immediately recorded for $90 \mathrm{sec}$ at $240 \mathrm{~nm}$. The blank consisted of extraction buffer instead of sample. Absorbance of the blank was subtracted

243 from that of the samples. Activities are expressed in $U / m g$ protein where $1 \mathrm{U}$ is the amount 244 of enzyme necessary for catalyzing $1 \mu$ mole of $\mathrm{H}_{2} \mathrm{O}_{2}$ per min (using $\varepsilon_{\mathrm{H}_{2} \mathrm{O} 2,240}=0.04 \mathrm{mM}^{-1}$. cm $\left.245^{1}\right)$.

Total Glutathione Peroxidase and Selenium Glutathione Peroxidase (t-GPx and Se247 GPx, EC 1.11.1.9) activities were measured by monitoring the decrease in NADPH concentration at $340 \mathrm{~nm}$ (McFarland et al., 1999). The assay buffer consisted of $62.5 \mathrm{mM}$ Phosphate Buffer, $6.25 \mathrm{mM}$ EDTA, $2.5 \mathrm{mM} \mathrm{GSH}, 2.5 \mathrm{U} / \mathrm{mL}$ GR, $0.5 \mathrm{mM}$ NADPH. For t-GPx,

250 Cumene Hydroperoxide $(1.875 \mathrm{mM})$ was added to the assay buffer. For Se-GPx, $\mathrm{NaN}_{3}(1.25$ 
251

252

253

254

255

256

257

258

259

260

261

262

263

264

265

266

267

268

269

270

271

272

273

274

275

276

277

278

279

$\mathrm{mM})$ and $\mathrm{H}_{2} \mathrm{O}_{2}(0.3125 \mathrm{mM})$ were added. Fifty $\mu \mathrm{L}$ of protein supernatants were placed in the wells and the reaction was started by the addition of $200 \mu \mathrm{L}$ of the assay buffer. NADPH loss was recorded for $3 \mathrm{~min}$ at $25^{\circ} \mathrm{C}$. The blank consisted of extraction buffer instead of sample. Absorbance of the blank was subtracted from that of the samples. Enzyme activities are reported as $\mathrm{U} / \mathrm{mg}$ protein where one unit is the amount of enzyme necessary for oxidizing 1 $\mu$ mole of NADPH per min (using $\varepsilon_{\mathrm{NADPH}, 340}=6.22 \mathrm{mM}^{-1} . \mathrm{cm}^{-1}$ ).

Glutathione Reductase (GR, EC 1.8.1.7) was assessed following (Cribb et al., 1989). Briefly, $20 \mu \mathrm{L}$ of protein supernatants were loaded in triplicate wells and the reaction was initiated by addition of $170 \mu \mathrm{L}$ of assay buffer (100 mM Sodium Phosphate Buffer, $0.7 \mathrm{mM}$ NADPH, $0.09 \mathrm{mM}$ DTNB, $0.2 \mathrm{mM} \mathrm{GSSG}$ ). Kinetics of GR activity was assayed during $3 \mathrm{~min}$ at $412 \mathrm{~nm}$. The blank consisted of extraction buffer instead of sample. Absorbance of the blank was subtracted from that of the samples. Activities are expressed as $\mathrm{U} / \mathrm{mg}$ protein; one unit being defined as the amount of enzyme catalyzing $1 \mu$ mole of DTNB per min (using $\varepsilon_{\text {DTNB, } 412}$ $\left.=14.15 \mathrm{mM}^{-1} \cdot \mathrm{cm}^{-1}\right)$.

Glutathione-S-Transferase (GST, EC 2.5.1.18) was measured following (McFarland et al., 1999). Briefly, $15 \mu \mathrm{L}$ of protein supernatant or extraction buffer (for blanks) were placed in triplicate wells. The reaction was initiated by the addition of $200 \mu \mathrm{L}$ of assay buffer $(200 \mathrm{mM}$ Phosphate Buffer, $1 \mathrm{mM}$ CDNB, $1 \mathrm{mM} \mathrm{GSH}$ ) and absorbance was recorded for $3 \mathrm{~min}$ at 340 $\mathrm{nm}$. Absorbance of the blank was subtracted from that of the samples. GST activities are reported as $\mathrm{U} / \mathrm{mg}$ protein; one $\mathrm{U}$ being defined as the amount of enzyme catalyzing $1 \mu$ mole of CDNB per min (using $\varepsilon_{\mathrm{CDNB}, 340}=9.6 \mathrm{mM}^{-1} \cdot \mathrm{cm}^{-1}$ ).

Thioredoxin Reductase (TrxR, EC 1.8.1.9) was assessed following the conversion of DTNB into TNB (Smith and Levander, 2002). Briefly, $50 \mu \mathrm{L}$ of protein supernatant were loaded in triplicate wells and $200 \mu \mathrm{L}$ of assay buffer $(62.5 \mathrm{mM}$ Phosphate Buffer, $12.5 \mathrm{mM}$ EDTA, $0.3 \mathrm{mM}$ NADPH and 3.125 M DTNB) were added to initiate the reaction. Additionally, each sample was assayed in the presence of $20 \mu \mathrm{M}$ aurothioglucose (an inhibitor of TrxR), in order to assess non-TrxR activity contributions. After one minute of incubation at room temperature, kinetics were followed for $3 \mathrm{~min}$ at $412 \mathrm{~nm}$. The blank consisted of extraction buffer instead of sample. Absorbance of the blank was subtracted from that of the samples. 
Activities are expressed as $U / \mathrm{mg}$ protein; one $U$ being defined as the amount of enzyme producing $1 \mu$ mole of TNB per $\min \left(\varepsilon_{\mathrm{TNB}, 412}=13.6 \mathrm{mM}^{-1} . \mathrm{cm}^{-1}\right)$.

\section{Immune related enzymes}

For the Inducible Nitric Oxide Synthase activity (iNOS, EC 1.14.13.39) assay, we developed a non-radioactive method (appendix A). Briefly, $55 \mu \mathrm{L}$ of protein supernatants

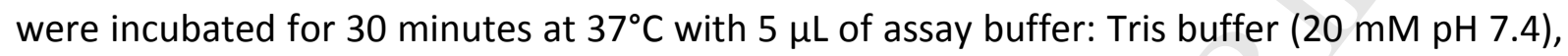
NADPH (1 mM), L-Arginine (1 mM), 5,6,7,8-tetrahydrobiopterin (10 $\mu \mathrm{M})$, FAD+ (5 $\mu \mathrm{M})$. Samples and blanks were also incubated with the same assay buffer containing L-NMMA $(200 \mu \mathrm{M})$, a specific inhibitor of NOS, in order to assess NOS activity alone. Blanks were run (PBS buffer instead of samples) and iNOS from mouse was used as a standard for the range curve. The reactions were stopped by addition of $200 \mu \mathrm{L}$ of the color developing reagent (COLDER, see description in appendix A) and the microplate was incubated at $95^{\circ} \mathrm{C}$ for 15 minutes. After 10 minutes at room temperature, L-citrulline formation was assessed by reading absorbance at $530 \mathrm{~nm}$. Absorbance of the blank and of samples incubated with LNMMA was subtracted from that of the samples. Activities are expressed in $\mathrm{U} / \mathrm{mg}$ protein where $1 \mathrm{U}$ is the amount of enzyme necessary to produce $1 \mu$ mole of L-citrulline per min.

Phenoloxidase activity was assessed according to (Le Bris et al., 2013). Briefly, $50 \mu \mathrm{L}$ of protein supernatants or extraction buffer (blank) were incubated with $50 \mu \mathrm{L}$ of Tris- $\mathrm{HCl}$ buffer $(0.10 \mathrm{M}, \mathrm{pH} 8.0)$ for 10 minutes at $25^{\circ} \mathrm{C}$. The reaction was initiated by addition of 100 $\mu \mathrm{L} 0.04 \mathrm{M} \mathrm{L-3,4-dihydroxyphenylalanine} \mathrm{(L-DOPA),} \mathrm{a} \mathrm{common} \mathrm{substrate} \mathrm{for} \mathrm{the} \mathrm{three} \mathrm{PO}$ subclasses. The increase in absorbance due to L-DOPA oxidation was monitored for 30 minutes at $492 \mathrm{~nm}$. The spontaneous oxidation of L-DOPA (blank) was also measured and subtracted from samples values. PO specific activities are expressed in units per mg protein using the following expression:

$$
P O(U / m g)=\left(\Delta O D / \min \times f_{d, s}\right) /[\text { protein }]
$$

Where $\Delta O D / \mathrm{min}$ is the value of increment of optical density per minute; $f_{d, s}$ is the dilution factor applied to the sample; and [protein] is the protein concentration of the sample in $\mathrm{mg} / \mathrm{mL}$. 


\subsection{Statistical analyses}

309

310

Given the unbalanced nature of the sampling design, injection, BRD status and sampling time were merged into one explanatory variable, hereafter referred to as "treatment". Treatments consist of seven conditions: control at 2 dpi, BRD- at 2dpi, control at $7 \mathrm{dpi}, \mathrm{BRD}-$ at $7 \mathrm{dpi}, \mathrm{BRD}+$ at $7 \mathrm{dpi}$, control at $30 \mathrm{dpi}$ and BRD+ at $30 \mathrm{dpi}$.

Non parametric Permutational Multivariate Analyses of Variance (PERMANOVA, (Anderson, 2001) were conducted on all biochemical variables for Ma and DG. This method allows partitioning the variance in response variables attributed to each explanatory variable (diet and treatment) and their interactions. A pseudo F-ratio, defined as the ratio of dissimilarity within a treatment and between treatments, is computed and its significance was tested by 999 permutations.

Ordination analyses were then performed using Principal Component Analysis (PCA) to plot individuals, variables and correlations between variables. A posteriori comparison tests were performed for each variable (ANOVA) in order to estimate the significance of results obtained with PERMANOVA. These analyses investigated the effect of diet, treatment and their interaction on biochemical parameters of clams. Analyses were first conducted with data collected at all sampling times and secondly for each sampling time.

Statistical analyses were carried out using R 3.1.2 Software (R Development Core Team, 2011). PERMANOVA were achieved using adonis function and the homogeneity of multivariate dispersions were tested using betadisper function from the vegan package (Oksanen et al., 2015). The rda function from vegan package was used for PCAs analyses and the subsequent biplots were drawed using ggplot2 package (Wickham and Chang, 2015). ANOVA using type III error were performed using the Anova function from the car package (Fox and Weisberg, 2010). 


\section{Results}

\subsection{Dietary fatty acid signatures}

The two cultured algae exhibited typical fatty acid profiles: $C$. calcitrans is rich in 20:5n-3 and 20:4n-6 and poor in 22:6n-3 whereas T-Iso is rich in 22:6n-3, deficient in 20:5n-3 and poor in 20:4n-6 (Table 2). Neutral lipids of clam DG at the end of the conditioning period clearly mirrored the fatty acid composition of the diet. For instance, DG of clams fed $C$. calcitrans were rich in 20:4n-6 and $20: 5 n-3$ and poor in $22: 6 n-3$ while this is the inverse pattern for those fed T-Iso (Table 3).

However, polar lipids of clam Ma at $7 \mathrm{dpi}$ were much less influenced by the diet. Indeed, levels of 20:4n-6, 20:5n-3, 22:6n-3, in polar lipids of animals fed $C$. calcitrans were $5.4 \%, 7.4 \%$, and $19.5 \%$ compared to $5.0 \%, 5.7 \%$, and $21.6 \%$ in those fed T-Iso, suggesting that selective incorporation/elimination of dietary fatty acids has occurred in this organ.

\subsection{Metabolic response of clam}

Overall, proximate composition (lipid, protein and carbohydrate content) and activities of enzymes related to energy, antioxidant and immunity in Ma of clams were not influenced by diet. However, most of these variables were greatly influenced by treatment (PERMANOVA, $r^{2}=0.30, F=2.19, p=0.029$ ).

At 2 and 7 dpi, activities of t-SOD, CAT, Se-GPx, GR, GST, iNOS and PO were markedly 352 influenced by the interaction of diet $x$ treatment (PERMANOVA, $r^{2}=0.28, F=4.08, p<0.01$ ). However, the effect of diet was not significant when PCAs and PERMANOVAs are conducted by day (Table 4). We therefore consider only treatment effects. from control at $2 \mathrm{dpi}$ (Figure 2). At $7 \mathrm{dpi}$, PCA discriminates clams injected with $V$. tapetis which did not exhibit clinical signs of disease development (BRD-) from those which were visibly unhealthy (BRD+) and control. Activities of t-SOD, CAT, Se-GPx, GR and PO were correlated together along with positive values of the first principal component axis (PC1) whereas proximate compositions were correlated together along with PC1 negative values. 
361

362

363

364

365

366

367

368

369

370

371

372

373

374

375

376

377

Activities of $\mathrm{Cu} / \mathrm{Zn}-\mathrm{SOD}$ and TrxR were respectively correlated with negative and with positive values of the second principal component (PC2).

At 2 dpi, activities of $\mathrm{Cu} / \mathrm{Zn}-\mathrm{SOD}$ and CAT were not significantly influenced by injection x BRD status, although they were respectively $23 \%$ lower and $27 \%$ higher in BRDthan in control (Figure 3, Appendix B). Also, activity of Se-GPx in BRD- was $46 \%$ lower than that of control. Finally, activity of iNOS was $24 \%$ higher in BRD- than that of control.

At $7 \mathrm{dpi}$, activities of antioxidant enzymes (t-SOD, CAT, GR) and PO in BRD-were 20 to $40 \%$ higher than those recorded in other animals, regardless of sampling times and BRD status (Figure 3, Appendix B). Activity of Se-GPx in BRD+ was $54 \%$ lower that of BRD- at 7 dpi (Figure 3, Appendix B). Activity of GST was not significantly impacted by treatment at $7 \mathrm{dpi}$, although it was 29 \% lower in BRD+ than in control and BRD- (Appendix B). Finally, activity of iNOS in BRD+ was $30 \%$ higher than that of control at 2 and 7 dpi and BRD- at 7 dpi (Figure 3, Appendix B).

At 30 dpi, principal component analysis (PCA) and PERMANOVA by sampling times showed that there was no significant effect at this sampling time (Table 4).

\section{Discussion}

\subsection{Diet effect on clam response to $V$. tapetis}

The two culture algae exhibited typical fatty acid profiles which were mirrored in the neutral lipids of the DG as previously reported in other bivalve species (Delaunay et al., 1993; Soudant et al., 1996, 1999). However, polar lipids of clam MA at 7 dpi were much less influenced by the diet, suggesting that selective incorporation of dietary fatty acids has occurred in this organ. Although selective incorporation of essential fatty acids in polar lipids is common in bivalves (Delaunay et al., 1993; Soudant et al., 1996; Copeman et al., 2002; Pernet and Tremblay, 2004), this phenomenon has rarely been observed to such an extent. For instance, polar lipids of clam haemocytes are reflective of the diet and clearly influence their functions (Delaporte et al., 2003, 2006, 2007; Dudognon et al., 2014). Our result may 
388

389

390

391

392

393

394

395

396

397

398

399

400

401

402

403

404

405

406

407

408

409

410

411

412

413

414

415

416

then reflect differences between organs abilities to regulate PUFAs in polar lipids and/or differences related to batch origin (Napolitano and Ackman, 1992; Soudant et al., 1999; Pernet et al., 2008).

Finally, the fact that dietary deficiencies were compensated in clam mantle may explain that disease prevalence and intensities, as well as activities of immunity-, antioxidant- and energy metabolism-related enzymes were not influenced by diet in this organ.

\subsection{Metabolic response of clam to $V$. tapetis}

Activities of antioxidant and immune-related enzymes of clams injected with $V$. tapetis changed between $2 \mathrm{dpi}$ and $7 \mathrm{dpi}$ concomitantly with increasing prevalence of BRD and changes in BRD status (Richard, 2015). In our study, biochemical parameters were measured in mature males only. Therefore, our results may not be fully representative of clam populations which generally consist of a mixture of males and females at different reproductive stages. However, the effects of sex and reproductive stage on enzyme activity in bivalves have received very little attention. The only available information is that sex and reproductive investment do not influence activities of antioxidant enzymes in gills of oysters (Béguel et al., 2013).

\subsubsection{Early response at $2 \mathrm{dpi}$}

In V. tapetis injected clams, activity of Cu/Zn-SOD tends to decrease (-23\%) whereas activity of iNOS was significantly higher than in the control (+24\%), likely leading to higher concentration of $\mathrm{O}_{2}{ }^{-}$and $\mathrm{NO}$ in $\mathrm{Ma}$ of BRD-. Indeed, previous studies reported that productions of ROS and RNS are enhanced to neutralize pathogens in bivalves (Arumugan et al., 2000; Tafalla et al., 2002; Bugge et al., 2007; Villamil et al., 2007; Costa et al., 2008). In particular, the enhancement of iNOS in BRD- agrees with an in vitro analysis of body fluids of clams exposed to $V$. tapetis that showed higher levels of nitrates and nitrites, two breakdown products of NO decomposition as compared to unexposed controls (Jeffroy and Paillard, 2011). Finally, increasing concentrations of both $\mathrm{O}_{2}{ }^{--}$and $\mathrm{NO}$ might lead to the formation of peroxinitrite (ONOO-), a RNS highly toxic to pathogen (Torreilles and Guerin, 1999; Donaghy et al., 2015). 
Activity of Se-GPx, an enzyme involved in peroxides decomposition, was markedly

418 lowered in BRD- (-46 \% compared to control), suggesting ROS accumulation in Ma. However, 419 this effect might be counterbalanced by the activity of CAT, an enzyme also involved in 420 peroxide detoxification, which tended to increase in BRD- (+27\% compared to control). The 421 complementary role of CAT and GPx has already been observed in clams Meretrix meretrix 422 challenged with Vibrio parahaemolyticus (Wang et al., 2011, 2013).

\subsubsection{Late response at $7 \mathrm{dpi}$}

424

\section{Resistance to BRD clinical signs appearance is associated to higher detoxication of ROS and} PO activities

Activities of several antioxidant enzymes (t-SOD, CAT) were markedly increased in BRD-, compared to BRD+ and control, at 2 and $7 \mathrm{dpi}$ (respectively, $+22 \%$ and $+41 \%$ ). Overactivation of these antioxidant enzymes in BRD- coincided with an increase in GR activity (+22\% compared to control and BRD+ at 2 and $7 \mathrm{dpi}$ ), likely reflecting the regulation of glutathione redox status for its further use, both in Se-GPx functioning and also as a nonenzymatic antioxidant (Winston and Digiulio, 1991; Hermes-Lima, 2004). Overall, the enhancement of antioxidant pathways in BRD- could indicate an efficient ROS scavenging compared to BRD+. These results showed that over-activation of antioxidant enzymes in clams may thus be related to their resistance to BRD clinical signs appearance. Although increasing antioxidant enzymes activities during early exposure of bivalves to vibriosis was already reported (Canesi et al., 2010; Genard et al., 2013), this phenomenon has never been related to the resistance to BRD clinical signs appearance.

Concomitantly, the activity of PO was $31 \%$ higher in BRD- compared to that of BRD+ and control at 2 and $7 \mathrm{dpi}$. Interestingly, oysters Saccostrea glomerata selectively bred for QX disease resistance exhibit a similar increase in PO activity compared to wild animals (Butt and Raftos, 2008). It is therefore likely that increased PO activity in clams exposed to $V$. tapetis is related to a resistance to BRD clinical signs appearance as previously suggested for antioxidant enzymes.

Taken together, these results suggest that in $V$. tapetis-challenged clams at $7 \mathrm{dpi}$, a resistance to BRD clinical signs appearance can be measured and was associated with 
446

447

448

449

450

451

452

453

454

455

456

457

458

459

460

461

462

463

464

465

466

467

468

469

470

471

472

473

474

detoxification of ROS by antioxidant enzymes and the production of toxic quinones through PO.

Appearance of BRD clinical signs is associated with lower GST activities and higher iNOS activities

The activity of GST, an enzyme associated with xenobiotics and lipid peroxide detoxification, tended to be lower in BRD+ compared to that of BRD- and control at $7 \mathrm{dpi}$ ($29 \%)$. Concomitantly, t-SOD, CAT and Se-GPx activities of BRD+ were lower than those of BRD- at 7 dpi (respectively, $-22 \%,-41 \%$ and $-54 \%$ ). Altogether, our results could suggest that BRD+ were exposed to higher level of peroxidized lipids and ROS at $7 \mathrm{dpi}$ than BRD- as lipid peroxidation increase has previously been associated to decreased antioxidant activities in M. edulis (Viarengo et al., 1991; Power and Sheehan, 1996). However, unsaturation index of polar lipids, an indicator of lipid peroxidation (Hulbert, 2003; Munro and Blier, 2012), was similar in BRD-, BRD+ and control at $7 \mathrm{dpi}$, such that the reduction in GST and antioxidant activities in BRD+ was not sufficient to alter the polar lipids of clams.

In addition, the activity of iNOS was $20 \%$ higher in BRD+ compared to that of control clams at 2 and $7 \mathrm{dpi}$ and BRD- at $7 \mathrm{dpi}$, likely leading to higher levels of NO and RNS in these animals, as previously reported (Jeffroy and Paillard, 2011). Over activation of iNOS had already been reported at $2 \mathrm{dpi}$ as an early response to $V$. tapetis injection, and BRD+ at $7 \mathrm{dpi}$ may keep on producing RNS to fight bacterial infection.

\section{Conclusion}

Antioxidant and immune responses were strongly influenced by BRD development in clams exposed to $V$. tapetis. An early response was observed at $2 \mathrm{dpi}$ in visibly healthy clams (BRD-). This early response consisted of a decrease in antioxidant activities, likely leading to accumulation of ROS to cope with bacterial infection. Then, at $7 \mathrm{dpi}$, clams that remained BRD- exhibited an over-activation of PO and antioxidant enzymes compared to diseased animals (BRD+). Therefore, activities of antioxidant and immune related enzymes are biomarkers of resistance to BRD development in clam. This study provides a better understanding of the antioxidant response of clams to the disease and it shows for the first time that iNOS takes part in the in vivo response of a bivalve species to its pathogen. 


\section{Acknowledgements}

476 This work was supported by the "Laboratoire d'Excellence" LabexMER (ANR-10-LABX-19) and

477 co-funded by a grant from the French government under the program "Investissements

478 d'Avenir" and by a grant from the Regional Council of Brittany. This work was also supported

479 by University of Western Brittany. We would first like to thank F. Fonteneau for providing 480 the clams, C. Quéré for her help with fatty acid analyses, P. Miner for his help with 481 experimental design and maintenance, and A. Bidault, N. Le Goïc, F. Nunes, H. Hégaret, C. 482 Fabioux, I. Paul-Pont, F. Le Grand, F. Riera, A.L. Cassone, P. Le Souchu, A. Muir, E. Harney, Y. 483 Epelboin, M. Fuhrmann, M. Provost, L. Frère, F. Boullot, B. Dubief, M. Czamanski, R. 484 Morvezen, V. Foulon, M. Protat, A. Guyon, and L. Delisle for their help with sampling and O. 485 Gauthier for advices in statistical analysis. Special thanks are addressed to E. Harney for 486 linguistic revision. 


\section{References}

488

489

490

491

492

493

494

495

496

497

498

499

500

501

502

503

504

505

506

507

508

509

510

511

512

513

514

515

516

517

518

519

520

521

522

523

524

525

526

527

528

529

530

531

Aebi, H., 1984. Catalase In vitro. Methods Enzymol. 105, 121-126.

Aladaileh, S., Nair, S.V., Raftos, D.A., 2007. Induction of phenoloxidase and other immunological activities in Sydney rock oysters challenged with microbial pathogenassociate molecular patterns. Fish Shellfish Immunol. 23, 1196-1208. doi:10.1016/j.fsi.2007.05.003

Allam, B., Paillard, C., Ford, S.E., 2002. Pathogenicity of Vibrio tapetis, the etiological agent of brown ring disease in clams. Dis. Aquat. Organ. 48, 221-231. doi:10.3354/dao048221

Anderson, M.J., 2001. A new method for non-parametric multivariate analysis of variance. Austral Ecol. 26, 32-46. doi:10.1046/j.1442-9993.2001.01070.x

Arumugan, M., Romestand, B., Torreilles, J., 2000. Nitrite released in haemocytes from Mytilus galloprovincialis, Crassostrea gigas and Ruditapes decussatus upon stimulation with phorbol myristate acetate. Aquat. Living Resour. 13, 173-177. doi:10.1016/S0990-7440(00)00150-9

Béguel, J.-P., Huvet, A., Quillien, V., Lambert, C., Fabioux, C., 2013. Study of the antioxidant capacity in gills of the Pacific oyster Crassostrea gigas in link with its reproductive investment. Comp. Biochem. Physiol. C-Toxicol. Pharmacol. 157, 63-71. doi:10.1016/j.cbpc.2012.10.004

Bugge, D.A., Hegaret, H., Wikfors, G.H., Allam, B., 2007. Oxidative burst in hard clam (Mercenaria mercenaria) haemocytes. Fish Shellfish Immunol. 23, 188-196. doi:10.1016/j.fsi.2006.10.006

Butt, D., Raftos, D., 2008. Phenoloxidase-associated cellular defence in the Sydney rock oyster, Saccostrea glomerata, provides resistance against QX disease infections. Dev. Comp. Immunol. 32, 299-306. doi:10.1016/j.dci.2007.06.006

Canesi, L., Barmo, C., Fabbri, R., Ciacci, C., Vergani, L., Roch, P., Gallo, G., 2010. Effects of vibrio challenge on digestive gland biomarkers and antioxidant gene expression in Mytilus galloprovincialis. Comp. Biochem. Physiol. C-Toxicol. Pharmacol. 152, 399406. doi:10.1016/j.cbpc.2010.06.008

Cerenius, L., Lee, B.L., Soderhall, K., 2008. The proPO-system: pros and cons for its role in invertebrate immunity. Trends Immunol. 29, 263-271. doi:10.1016/j.it.2008.02.009

Chen, G.A., Gharib, T.G., Huang, C.C., Taylor, J.M.G., Misek, D.E., Kardia, S.L.R., Giordano, T.J., lannettoni, M.D., Orringer, M.B., Hanash, S.M., Beer, D.G., 2002. Discordant protein and mRNA expression in lung adenocarcinomas. Mol. Cell. Proteomics 1, 304-313. doi:10.1074/mcp.M200008-MCP200

Childress, J., Somero, G., 1979. Depth-Related Enzymic Activities in Muscle, Brain and Heart of Deep-Living Pelagic Marine Teleosts. Mar. Biol. 52, 273-283. doi:10.1007/BF00398141

Chu, F.L.E., 2000. Defense mechanisms of marine bivalves.

Copeman, L.A., Parrish, C.C., Brown, J.A., Harel, M., 2002. Effects of docosahexaenoic, eicosapentaenoic, and arachidonic acids on the early growth, survival, lipid composition and pigmentation of yellowtail flounder (Limanda ferruginea): a live food enrichment experiment. Aquaculture 210, 285-304. doi:10.1016/S00448486(01)00849-3

Corporeau, C., Vanderplancke, G., Boulais, M., Suquet, M., Quere, C., Boudry, P., Huvet, A., Madec, S., 2012. Proteomic identification of quality factors for oocytes in the Pacific 
532

533

534

535

536

537

538

539

540

541

542

543

544

545

546

547

548

549

550

551

552

553

554

555

556

557

558

559

560

561

562

563

564

565

566

567

568

569

570

571

572

573

574

575

576

577

578 oyster Crassostrea gigas. J. Proteomics 75, 5554-5563.

doi:10.1016/j.jprot.2012.07.040

Costa, M.M., Novoa, B., Figueras, A., 2008. Influence of beta-glucans on the immune responses of carpet shell clam (Ruditapes decussatus) and Mediterranean mussel (Mytilus galloprovincialis). Fish Shellfish Immunol. 24, 498-505. doi:10.1016/j.fsi.2007.10.003

Cribb, A., Leeder, J., Spielberg, S., 1989. Use of a Microplate Reader in an Assay of Glutathione-Reductase Using 5,5'-Dithiobis(2-Nitrobenzoic Acid). Anal. Biochem. 183, 195-196. doi:10.1016/0003-2697(89)90188-7

Dalsgaard, J., St John, M., Kattner, G., Muller-Navarra, D., Hagen, W., 2003. Fatty acid trophic markers in the pelagic marine environment. Adv. Mar. Biol. Vol 46 46, 225-340. doi:10.1016/S0065-2881(03)46005-7

Delaporte, M., Soudant, P., Lambert, C., Jegaden, M., Moal, J., Pouvreau, S., Degremont, L., Boudry, P., Samain, J.-F., 2007. Characterisation of physiological and immunological differences between Pacific oysters (Crassostrea gigas) genetically selected for high or low survival to summer mortalities and fed different rations under controlled conditions. J. Exp. Mar. Biol. Ecol. 353, 45-57. doi:10.1016/j.jembe.2007.09.003

Delaporte, M., Soudant, P., Moal, J., Giudicelli, E., Lambert, C., Seguineau, C., Samain, J.-F., 2006. Impact of $20: 4 n-6$ supplementation on the fatty acid composition and hemocyte parameters of the Pacific oyster Crassostrea gigas. Lipids 41, 567-576. doi:10.1007/s11745-006-5006-9

Delaporte, M., Soudant, P., Moal, J., Lambert, C., Quere, C., Miner, P., Choquet, G., Paillard, C., Samain, J.F., 2003. Effect of a mono-specific algal diet on immune functions in two bivalve species - Crassostrea gigas and Ruditapes philippinarum. J. Exp. Biol. 206, 3053-3064. doi:10.1242/jeb.00518

Delaunay, F., Marty, Y., Moal, J., Samain, J., 1993. The Effect of Monospecific Algal Diets on Growth and Fatty-Acid Composition of Pecten-Maximus (I) Larvae. J. Exp. Mar. Biol. Ecol. 173, 163-179. doi:10.1016/0022-0981(93)90051-0

Development Core Team, R., 2011. R: A Language and Environment for Statistical Computing. Vienna, Austria: the R Foundation for Statistical Computing.

Donaghy, L., Hong, H.-K., Jauzein, C., Choi, K.-S., 2015. The known and unknown sources of reactive oxygen and nitrogen species in haemocytes of marine bivalve molluscs. Fish Shellfish Immunol. 42, 91-97. doi:10.1016/j.fsi.2014.10.030

Dubois, M., Gilles, K., Hamilton, J., Rebers, P., Smith, F., 1956. Colorimetric Method for Determination of Sugars and Related Substances. Anal. Chem. 28, 350-356. doi:10.1021/ac60111a017

Dudognon, T., Lambert, C., Quere, C., Auffret, M., Soudant, P., Kraffe, E., 2014. Mitochondrial activity, hemocyte parameters and lipid composition modulation by dietary conditioning in the Pacific oyster Crassostrea gigas. J. Comp. Physiol. BBiochem. Syst. Environ. Physiol. 184, 303-317. doi:10.1007/s00360-013-0800-1

Ellis, R.P., Parry, H., Spicer, J.I., Hutchinson, T.H., Pipe, R.K., Widdicombe, S., 2011. Immunological function in marine invertebrates: Responses to environmental perturbation. Fish Shellfish Immunol. 30, 1209-1222. doi:10.1016/j.fsi.2011.03.017

Flye-Sainte-Marie, J., Pouvreau, S., Paillard, C., Jean, F., 2007. Impact of Brown Ring Disease on the energy budget of the Manila clam Ruditapes philippinarum. J. Exp. Mar. Biol. Ecol. 349, 378-389. doi:10.1016/j.jembe.2007.05.029

Fox, J., Weisberg, S., 2010. An R Companion to Applied Regression. SAGE. 
Genard, B., Miner, P., Nicolas, J.-L., Moraga, D., Boudry, P., Pernet, F., Tremblay, R., 2013. Integrative Study of Physiological Changes Associated with Bacterial Infection in Pacific Oyster Larvae. Plos One 8, e64534. doi:10.1371/journal.pone.0064534

Goulletquer, P., 1989. Etude des facteurs environnementaux intervenant sur la production de la palourde japonaise d'élevage Ruditapes philippinarum. Université de Bretagne occidentale, Brest.

Greenway, S.C., Storey, K.B., 1999. The effect of prolonged anoxia on enzyme activities in oysters (Crassostrea virginica) at different seasons. J. Exp. Mar. Biol. Ecol. 242, 259272. doi:10.1016/S0022-0981(99)00103-3

Hausladen, A., Stamler, J.S., 1999. Nitrosative stress. Oxid. Antioxid. Pt B 300, 389-395. Hermes-Lima, M., 2004. Oxygen in Biology and Biochemistry: Role of Free Radicals, in: Ph.D, K.B.S. (Ed.), Functional Metabolism. John Wiley \& Sons, Inc., pp. 319-368.

Hulbert, A.J., 2003. Life, death and membrane bilayers. J. Exp. Biol. 206, 2303-2311.

Jeffroy, F., Paillard, C., 2011. Involvement of nitric oxide in the in vitro interaction between Manila clam, Ruditapes philippinarum, hemocytes and the bacterium Vibrio tapetis. Fish Shellfish Immunol. 31, 1137-1141. doi:10.1016/j.fsi.2011.10.008

Le Bris, C., Paillard, C., Stiger-Pouvreau, V., Guerard, F., 2013. Laccase-like activity in the hemolymph of Venerupis philippinarum: Characterization and kinetic properties. Fish Shellfish Immunol. 35, 1804-1812. doi:10.1016/j.fsi.2013.09.009

Le Bris, C., Richard, G., Paillard, C., Lambert, C., Seguineau, C., Gauthier, O., Pernet, F., Guerard, F., 2015. Immune responses of phenoloxidase and superoxide dismutase in the manila clam Venerupis philippinarum challenged with Vibrio tapetis - Part I: Spatio-temporal evolution of enzymes' activities post-infection. Fish Shellfish Immunol. 42, 16-24. doi:10.1016/j.fsi.2014.10.021

Lesser, M.P., 2006. Oxidative stress in marine environments: Biochemistry and physiological ecology, in: Annual Review of Physiology. pp. 253-278.

Luna-Acosta, A., Saulnier, D., Pommier, M., Haffner, P., De Decker, S., Renault, T., ThomasGuyon, H., 2011. First evidence of a potential antibacterial activity involving a laccase-type enzyme of the phenoloxidase system in Pacific oyster Crassostrea gigas haemocytes. Fish Shellfish Immunol. 31, 795-800. doi:10.1016/j.fsi.2011.07.016

Manduzio, H., Rocher, B., Durand, F., Galap, C., Leboulenger, F., 2005. The point about oxidative stress in molluscs. ISJ 2.

Marty, Y., Delaunay, F., Moal, J., Samain, J., 1992. Changes in the Fatty-Acid Composition of Pecten Maximus (I) During Larval Development. J. Exp. Mar. Biol. Ecol. 163, 221-234. doi:10.1016/0022-0981(92)90051-B

McFarland, V.A., Inouye, L.S., Lutz, C.H., Jarvis, A.S., Clarke, J.U., McCant, D.D., 1999. Biomarkers of oxidative stress and genotoxicity in livers of field-collected brown bullhead, Ameiurus nebulosus. Arch. Environ. Contam. Toxicol. 37, 236-241.

Metcalfe, L.D., Schmitz, A.A., 1961. The Rapid Preparation of Fatty Acid Esters for Gas Chromatographic Analysis. Anal. Chem. 33, 363-364. doi:10.1021/ac60171a016

Munro, D., Blier, P.U., 2012. The extreme longevity of Arctica islandica is associated with increased peroxidation resistance in mitochondrial membranes. Aging Cell 11, 845855.

Napolitano, G., Ackman, R., 1992. Anatomical Distributions and Temporal Variations of Lipid Classes in Sea Scallops Placopecten Magellanicus (gmelin) from Georges Bank (novaScotia). Comp. Biochem. Physiol. B-Biochem. Mol. Biol. 103, 645-650. doi:10.1016/0305-0491(92)90384-4 
Oksanen, J., Blanchet, F.G., Kindt, R., Legendre, P., Minchin, P.R., O'Hara, R.B., Simpson, G.L., Solymos, P., Stevens, M.H.H., Wagner, H., 2015. vegan: Community Ecology Package.

Paillard, C., 2004. A short-review of brown ring disease, a vibriosis affecting clams, Ruditapes philippinarum and Ruditapes decussatus. Aquat. Living Resour. 17, 467-475. doi:10.1051/alr:2004053

Paillard, C., Maes, P., 1995. The Brown Ring Disease in the Manila Clam, Ruditapes Philippinarum .1. Ultrastructural Alterations of the Periostracal Lamina. J. Invertebr. Pathol. 65, 91-100. doi:10.1006/jipa.1995.1015

Paillard, C., Maes, P., 1994. Brown Ring Disease in the Manila Clam Ruditapes Philippinarum Establishment of a Classification-System. Dis. Aquat. Organ. 19, 137-146. doi:10.3354/dao019137

Paillard, C., Maes, P., Oubella, R., 1994. Brown ring disease in clams. Annu. Rev. Fish Dis. 4, 219-240.

Pernet, F., Tremblay, R., 2004. Effect of varying levels of dietary essential fatty acid during early ontogeny of the sea scallop Placopecten magellanicus. J. Exp. Mar. Biol. Ecol. 310, 73-86. doi:10.1016/j.jembe.2004.04.001

Pernet, F., Tremblay, R., Redjah, I., Sevigny, J.-M., Gionet, C., 2008. Physiological and biochemical traits correlate with differences in growth rate and temperature adaptation among groups of the eastern oyster Crassostrea virginica. J. Exp. Biol. 211, 969-977. doi:10.1242/jeb.014639

Pipe, R., Coles, J., 1995. Environmental Contaminants Influencing Immune Function in Marine Bivalve Mollusks. Fish Shellfish Immunol. 5, 581-595. doi:10.1016/S10504648(95)80043-3

Plana, S., 1995. Perturbations de la glande digestive et du métabolisme chez la palourde aquacole, Ruditapes Philippinarum, affectée par la maladie de l'anneau brun (PhD thesis). Université de Bretagne occidentale, France.

Plana, S., Sinquin, G., Maes, P., Paillard, C., Le Pennec, M., 1996. Variations in biochemical composition of juvenile Ruditapes philippinarum infected by a Vibrio sp. Dis. Aquat. Organ. 24, 205-213. doi:10.3354/dao024205

Power, A., Sheehan, D., 1996. Seasonal variation in the antioxidant defence systems of gill and digestive gland of the blue mussel, Mytilus edulis. Comp. Biochem. Physiol. CPharmacol. Toxicol. Endocrinol. 114, 99-103. doi:10.1016/0742-8413(96)00024-2

Powis, G., Montfort, W.R., 2001. Properties and biological activities of thioredoxins. Annu. Rev. Biophys. Biomol. Struct. 30, 421-455. doi:10.1146/annurev.biophys.30.1.421

Revathy, K.S., Umasuthan, N., Lee, Y., Choi, C.Y., Whang, I., Lee, J., 2012a. First molluscan theta-class Glutathione S-Transferase: Identification, cloning, characterization and transcriptional analysis post immune challenges. Comp. Biochem. Physiol. B-Biochem. Mol. Biol. 162, 10-23. doi:10.1016/j.cbpb.2012.02.004

Revathy, K.S., Umasuthan, N., Lee, Y., Whang, I., Kim, H.C., Lee, J., 2012b. Cytosolic thioredoxin from Ruditapes philippinarum: Molecular cloning, characterization, expression and DNA protection activity of the recombinant protein. Dev. Comp. Immunol. 36, 85-92. doi:10.1016/j.dci.2011.06.006

Richard, G., 2015. Approche mécanistique de la réponse de la palourde japonaise, Ruditapes philippinarum, exposée à la bactérie Vibrio tapetis : influence de la température et du régime algal. Université de Bretagne Occidentale, Brest.

Richard, G., Le Bris, C., Guerard, F., Lambert, C., Paillard, C., 2015. Immune responses of phenoloxidase and superoxide dismutase in the manila clam Venerupis philippinarum 
673

674

675

676

677

678

679

680

681

682

683

684

685

686

687

688

689

690

691

692

693

694

695

696

697

698

699

700

701

702

703

704

705

706

707

708

709

710

711

712

713

714

715

716

717

challenged with Vibrio tapetis - Part II: Combined effect of temperature and two V. tapetis strains. Fish Shellfish Immunol. 44, 79-87. doi:10.1016/j.fsi.2014.12.039

Sies, H., 1993. Strategies of Antioxidant Defense. Eur. J. Biochem. 215, 213-219. doi:10.1111/j.1432-1033.1993.tb18025.x

Smith, A.D., Levander, O.A., 2002. High-throughput 96-well microplate assays for determining specific activities of glutathione peroxidase and thioredoxin reductase. Protein Sens. React. Oxyg. Species Pt Selenoproteins Thioredoxin 347, 113-121.

Soudant, P., Chu, F.-L.E., Volety, A., 2013. Host-parasite interactions: Marine bivalve molluscs and protozoan parasites, Perkinsus species. J. Invertebr. Pathol. 114, 196-216. doi:10.1016/j.jip.2013.06.001

Soudant, P., Marty, Y., Moal, J., Robert, R., Quere, C., LeCoz, J.R., Samain, J.F., 1996. Effect of food fatty acid and sterol quality on Pecten maximus gonad composition and reproduction process. Aquaculture 143, 361-378. doi:10.1016/0044-8486(96)012768

Soudant, P., Van Ryckeghem, K., Marty, Y., Moal, J., Samain, J.F., Sorgeloos, P., 1999. Comparison of the lipid class and fatty acid composition between a reproductive cycle in nature and a standard hatchery conditioning of the Pacific Oyster Crassostrea gigas. Comp. Biochem. Physiol. B-Biochem. Mol. Biol. 123, 209-222. doi:10.1016/S0305-0491(99)00063-2

Tafalla, C., Novoa, B., Figueras, A., 2002. Production of nitric oxide by mussel (Mytilus galloprovincialis) hemocytes and effect of exogenous nitric oxide on phagocytic functions. Comp. Biochem. Physiol. B-Biochem. Mol. Biol. 132, 423-431.

Torreilles, J., Guerin, M.C., 1999. Production of peroxynitrite by zymosan stimulation of Mytilus galloprovincialis haemocytes in vitro. Fish Shellfish Immunol. 9, 509-518. doi:10.1006/fsim.1998.0200

Trinkler, N., Sinquin, G., Querne, J., Paillard, C., 2010. Resistance to Brown Ring Disease in the Manila clam, Ruditapes philippinarum: A study of selected stocks showing a recovery process by shell repair. J. Invertebr. Pathol. 104, 8-16. doi:10.1016/j.jip.2009.12.007

Umasuthan, N., Bathige, S.D.N.K., Revathy, K.S., Lee, Y., Whang, I., Choi, C.Y., Park, H.-C., Lee, J., 2012a. A manganese superoxide dismutase (MnSOD) from Ruditapes philippinarum: Comparative structural- and expressional-analysis with copper/zinc superoxide dismutase (Cu/ZnSOD) and biochemical analysis of its antioxidant activities. Fish Shellfish Immunol. 33, 753-765. doi:10.1016/j.fsi.2012.06.024

Umasuthan, N., Revathy, K.S., Lee, Y., Whang, I., Choi, C.Y., Lee, J., 2012b. A novel molluscan sigma-like glutathione S-transferase from Manila clam, Ruditapes philippinarum: Cloning, characterization and transcriptional profiling. Comp. Biochem. Physiol. CToxicol. Pharmacol. 155, 539-550. doi:10.1016/j.cbpc.2012.01.001

Umasuthan, N., Revathy, K.S., Lee, Y., Whang, I., Lee, J., 2012c. Mitochondrial thioredoxin-2 from Manila clam (Ruditapes philippinarum) is a potent antioxidant enzyme involved in antibacterial response. Fish Shellfish Immunol. 32, 513-523. doi:10.1016/j.fsi.2011.12.010

Viarengo, A., Canesi, L., Pertica, M., Livingstone, D., Orunesu, M., 1991. Age-Related LipidPeroxidation in the Digestive Gland of Mussels - the Role of the Antioxidant Defense Systems. Experientia 47, 454-457. doi:10.1007/BF01959942 
Villamil, L., Gomez-Leon, J., Gomez-Chiarri, M., 2007. Role of nitric oxide in the defenses of Crassostrea virginica to experimental infection with the protozoan parasite Perkinsus marinus. Dev. Comp. Immunol. 31, 968-977. doi:10.1016/j.dci.2007.01.006

Wang, C., Huan, P., Yue, X., Yan, M., Liu, B., 2011. Molecular characterization of a glutathione peroxidase gene and its expression in the selected Vibrio-resistant population of the clam Meretrix meretrix. Fish Shellfish Immunol. 30, 1294-1302. doi:10.1016/j.fsi.2011.03.015

Wang, C., Yue, X., Lu, X., Liu, B., 2013. The role of catalase in the immune response to oxidative stress and pathogen challenge in the clam Meretrix meretrix. Fish Shellfish Immunol. 34, 91-99. doi:10.1016/j.fsi.2012.10.013

Wickham, H., Chang, W., 2015. ggplot2: An Implementation of the Grammar of Graphics.

Winston, G., Digiulio, R., 1991. Prooxidant and Antioxidant Mechanisms in Aquatic Organisms. Aquat. Toxicol. 19, 137-161. doi:10.1016/0166-445X(91)90033-6 
734

735

736

737

738

739

740

741

742

743

744

745

746

747

748

749

750

751

752

753

754

755

756

757

758

759

760

761

762

Figure 1: Commonly accepted enzymatic antioxidant pathways involved in reactive oxygen species (in red) and reactive nitrogen species (in blue) production and detoxication in bivalve mollusks hemocytes, in intracellular compartment (mitochondria, peroxisome, cytosol) and in extracellular compartment (plasma). Abbreviations: NADPH-Ox, NADPH oxidase; Cu/ZnSOD, Cu/Zn superoxide dismutase; Mn-SOD, Mn superoxide dismutase; EC-SOD, extracellular superoxide dismutase; CAT, catalase; GPx, glutathion peroxidase; GR, glutathion reductase; GST, glutathione-S-transferase; GSSG, oxidized glutathione; GSH, reduced glutathione; TrxP; thioredoxin peroxidase; TrxR, thioredoxin reductase; $\operatorname{Trx}(\mathrm{ox})$, oxidized thioredoxin; $\operatorname{Trx}(\mathrm{red})$, reduced thioredoxin; iNOS, inducible nitric oxide synthase; $\mathrm{O}_{2}{ }^{\circ}$, superoxide; $\mathrm{H}_{2} \mathrm{O}_{2}$, hydrogen peroxide; $\mathrm{ROOH}$, organic peroxides; $\mathrm{ROH}$, alcohols; $\mathrm{NO}^{\circ}$, nitric oxide; ONOO', peroxynitrite; $\mathrm{NO}_{2}{ }^{-}$, nitrite; L-ARG, L-Arginine; L-CIT, L-Citrulline.

Figure 2: Principal component analysis ordination biplot representing the effect of treatment on biochemical parameters of clams (lines) at 2 and 7 days post-injection (dpi). Clams were injected with filtered seawater (control) or with its pathogen Vibrio tapetis. Clams injected with $V$. tapetis were either BRD- (no clinical sign of infection) or BRD+ (visible brown ring). White symbols: control; grey symbols: BRD-; black symbols: BRD+. Triangles: $2 \mathrm{dpi}$; circles: 7 dpi. Abbreviations: t-SOD, total superoxide dismutase; $\mathrm{Cu} / \mathrm{Zn}-\mathrm{SOD}, \mathrm{Cu} / \mathrm{Zn}$ superoxide dismutase; Mn-SOD, Mn superoxide dismutase; CAT, catalase; t-GPx, total glutathion peroxidase; Se-GPx, selenium-dependant glutathione peroxidase; GR, glutathion reductase; GST, glutathione-S-transferase; TrxR, thioredoxin reductase; iNOS, inducible nitric oxide synthase; PO, phenoloxidase; HK, hexokinase ; PK, pyruvate kinase; CS, citrate synthase.

Figure 3: Biochemical parameters of clams at 2 and 7 days post-injection (dpi) with filtered seawater (control, white bars) or with $V$. tapetis. Clams injected with $V$. tapetis were either BRD- (no clinical sign of infection, grey bars) or BRD+ (visible brown ring, black bars). Abbreviations: t-SOD, total superoxide dismutase; $\mathrm{Cu} / \mathrm{Zn}$ SOD; $\mathrm{Cu} / \mathrm{Zn}$ superoxide dismutase; CAT, catalase; Se-GPx, selenium dependant glutathione peroxidase; GR, glutathione reductase; GST, glutathione-S-tranferase; iNOS, inducible nitric oxide synthase; PO, phenoloxidase. Specific enzyme activities are represented as mean \pm standard deviation (SD). Letters indicate significant differences. 
Nitric Oxide Synthases (NOS) are NADPH-dependant enzymes that convert L-Arginine

765

766

767

768

769

770

771

772

773

774

775

776

777

778

779

780

781

782

783

784

785

786

787

788

789

790

791

792 (L-ARG) into L-Citrulline (L-CIT) in the presence of its co-factors tetrabiopterin $\left(\mathrm{BH}_{4}\right)$ and $\mathrm{FAD}$ (Calderon-Cortes et al., 2006). In mammalian systems, three iso-enzymes of NOS are known: the neuronal and constitutive NOS (nNOS or NOS I), the inducible NOS originally found in macrophages (iNOS or NOS II), and the endothelial and constitutive NOS (eNOS or NOS III). Constitutive forms are calmodulin/ $/ \mathrm{Ca}^{2+}$ dependant while iNOS is calmodulin/ $/ \mathrm{Ca}^{2+}$ independent (Knowles and Moncada, 1994). Additionnally, iNOS has been characterized in haemocytes of the snail Viviparus ater and the oyster Crassostrea virginica (Conte and Ottaviani, 1995; Villamil et al., 2007).

Numerous studies examining iNOS immune role in bivalves used the Griess Reagent protocol which measures breakdown products of NO (nitrates and nitrites). Thus, this method is not considered as directly evaluating iNOS activity. The most sensitive method for NOS activity determination is based on the monitoring of radiolabelled L-ARG (Knowles and Moncada, 1994). However, this method is time-consuming, due to the chromatographic separation of L-CIT from L-ARG (Knipp and Vasak, 2000).

Here, we propose a protocol for determination of iNOS activity which is nonradioactive and directly measures the enzyme's product, L-CIT. Our method is based on that of Knipp and Vasak (Knipp and Vasak, 2000) and relies on L-citrulline formation detection.

Briefly, $55 \mu \mathrm{L}$ of protein supernatants were incubated during 30 minutes at $37^{\circ} \mathrm{C}$ with $5 \mu \mathrm{L}$ of assay buffer: Tris buffer (20 mM pH 7.4), NADPH (1 mM), L-Arginine (1 mM), 5.6.7.8tetrahydrobiopterin $(10 \mu \mathrm{M}), \mathrm{FAD}+(5 \mu \mathrm{M})$. As iNOS is $\mathrm{Ca}^{2+} /$ Calmodulin independent, contrarily to constitutive NOS, these reagents were not added to the reaction buffer (Cho et al., 1992; Gross, 1996). Samples were also incubated with the same assay buffer containing L-NMMA (200 $\mu \mathrm{M})$, a specific inhibitor of NOS, in order to assess specifically NOS activity (Knowles and Moncada, 1994). Blanks were run (PBS buffer instead of samples) and iNOS from mouse was used as a standard for range curve (Figure 1). The reactions were stopped by addition of $200 \mu \mathrm{L}$ of the colour developing reagent (COLDER): 2, 3-butanedione monoxime $(20 \mathrm{mM})$, thiosemicarbazide $(0.5 \mathrm{mM})$, phosphoric acid $(2.25 \mathrm{M})$, sulfuric acid (4.5 M), ammonium iron (III) sulfate dodecahydrate $(1.5 \mathrm{mM})$. Then, the microplate was 
793 immediately sealed with foil and placed on a preheated aluminium plate in an oven at $95^{\circ} \mathrm{C}$

794 for 15 minutes for colour development (Figure 2). After colour development, the microplate 795 was removed from the oven and allowed to cool down for 10 minutes at room temperature. 796 Absorbances were read at $530 \mathrm{~nm}$. Activities were calculated for each sample by 797 substracting blank values and activities obtained with L-NMMA inhibition, and expressed as $798 \mathrm{U} / \mathrm{mg}$ total protein $(1 \mathrm{U}$ corresponding to the amount of enzyme producing $1 \mu \mathrm{mole}$ of L799 citrulline per minute in the above conditions).

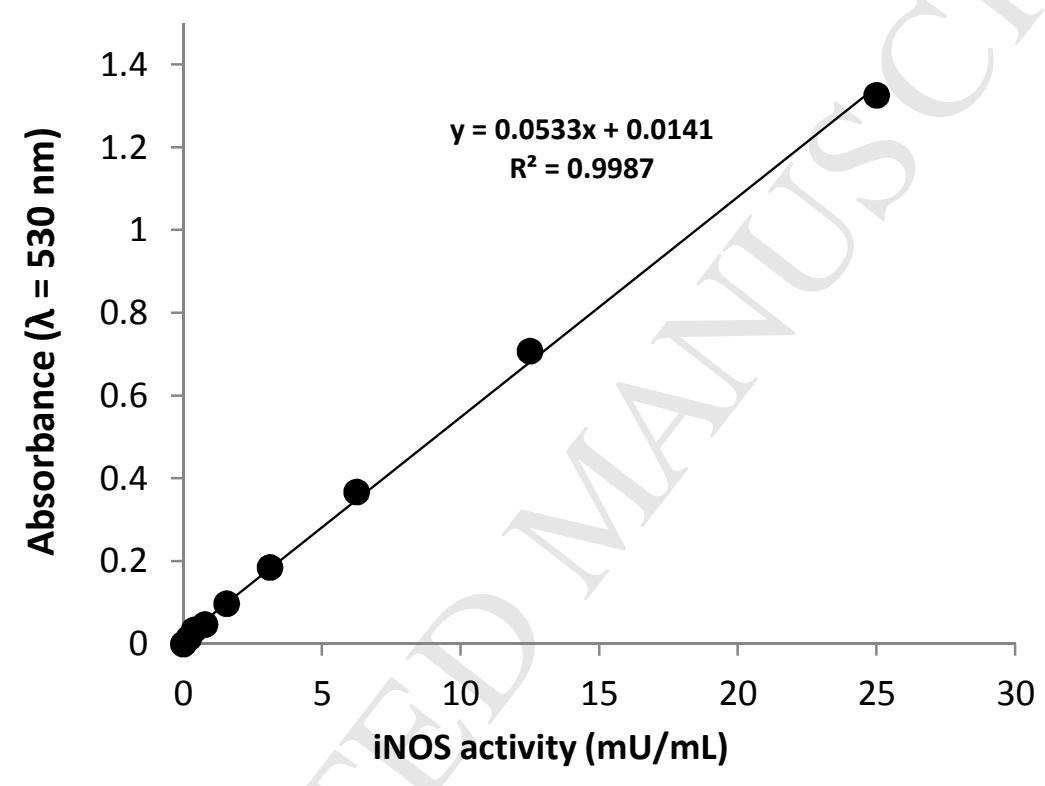

800

801 Figure 1: Example of standard curve obtained with iNOS from mouse following this protocol.

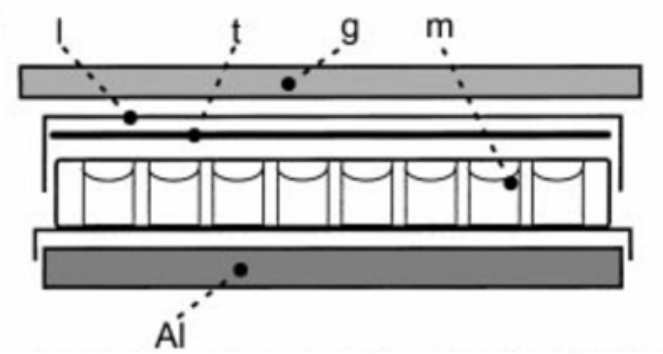

802 Figure 2: Setup for colour development - from Knipp \& Vasak. 2000.

803 Abbreviations: $m=$ microplate; $\mathrm{I}=$ lid of the microplate; $\mathrm{t}$ = thermoresistant sealing tape (foil 804 tape); $\mathrm{Al}=$ preheated aluminum plate $\left(\right.$ at $\left.95^{\circ} \mathrm{C}\right) ; \mathrm{g}=$ preheated glass plate $\left(\right.$ at $\left.95^{\circ} \mathrm{C}\right)$. 
805

806

807

808

809

810

811

812

813

814

815

816

817

818

819

820

821

822

823

824

825

826

\section{References}

Calderon-Cortes, E., Clemente-Guerrero, M., Sierra-Campos, E., Cortes-Rojo, C., GaonaZamudio, F.J., Villalobos-Molina, R., Saavedra-Molina, A., 2006. Functional characterization of brain mitochondrial nitric oxide synthase during hypertension and aging. Amino Acids 30, 73-80. doi:10.1007/s00726-005-0213-x

Cho, H., Xie, Q., Calaycay, J., Mumford, R., Swiderek, K., Lee, T., Nathan, C., 1992. Calmodulin Is a Subunit of Nitric Oxide Synthase from Macrophages. J. Exp. Med. 176, 599-604. doi:10.1084/jem.176.2.599

Conte, A., Ottaviani, E., 1995. Nitric Oxide Synthase Activity in Molluscan Hemocytes. Febs Lett. 365, 120-124. doi:10.1016/0014-5793(95)00439-G

Gross, S.S., 1996. Microtiter plate assay for determining kinetics of nitric oxide synthesis. Nitric Oxide Pt - Sources Detect. No No Synthase 268, 159-168.

Knipp, M., Vasak, M., 2000. A colorimetric 96-well microtiter plate assay for the determination of enzymatically formed citrulline. Anal. Biochem. 286, 257-264. doi:10.1006/abio.2000.4805

Knowles, R., Moncada, S., 1994. Nitric Oxide Synthases in Mammals. Biochem. J. 298, 249258.

Villamil, L., Gomez-Leon, J., Gomez-Chiarri, M., 2007. Role of nitric oxide in the defenses of Crassostrea virginica to experimental infection with the protozoan parasite Perkinsus marinus. Dev. Comp. Immunol. 31, 968-977. doi:10.1016/j.dci.2007.01.006 
827 Appendix B: Summaries of means \pm standard deviation and ANOVA for biochemical

828 parameters of clams at $\mathbf{2}$ and $\mathbf{7}$ days post-injection (dpi) with filtered seawater (control) or

829 with V. tapetis. Clams injected with V. tapetis were either BRD- (no clinical sign of infection)

830 or BRD+ (visible brown ring). Abbreviations: t-SOD, total superoxide dismutase; Cu/Zn-SOD,

$831 \mathrm{Cu} / \mathrm{Zn}$ superoxide dismutase; Mn-SOD, Mn superoxide dismutase; CAT, catalase; t-GPx,

832 total glutathion peroxidase; Se-GPx, selenium-dependant glutathione peroxidase; GR,

833 glutathion reductase; GST, glutathione-S-transferase; TrxR, thioredoxin reductase; iNOS,

834 inducible nitric oxide synthase; PO, phenoloxidase; HK, hexokinase; PK, pyruvate kinase;

835 CS, citrate synthase. Letters indicate significant differences.

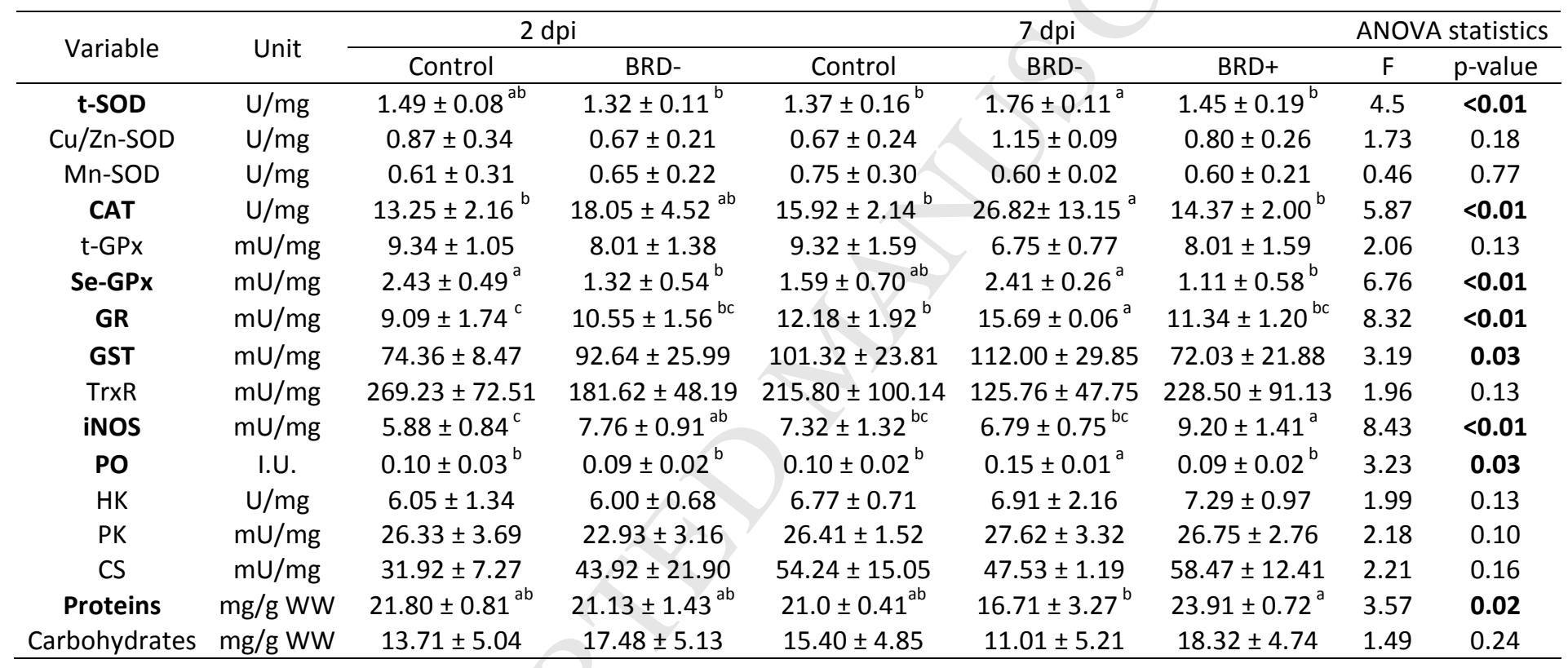




\section{ACCEPTED MANUSCRIPT}

Table 1: Sampling design. Clams were fed T-Isochrysis aff. galbana, clone Tahitian (T-Iso) or Chaetoceros calcitrans (C. calcitrans) and injected with Vibrio tapetis or filtered sea-water (FSW, Control). Clams injected with V. tapetis were either BRD- (no clinical sign of infection) or BRD+ (visible brown ring). Abbreviations: $\mathrm{P}$, pool number; $\mathrm{n}$, number of individuals for the pool; $\mathrm{T}$, tank number; dpi, days post-injection.

\begin{tabular}{|c|c|c|c|c|c|}
\hline Diet & Iniection & BRD & & Time (dpi) & 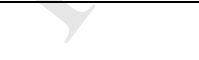 \\
\hline Die & mjection & status & 2 & 7 & 30 \\
\hline \multirow{4}{*}{ C. calcitrans } & \multirow{4}{*}{ FSW } & \multirow{4}{*}{ Control } & $P 1 n=3 T 4$ & $P 1 n=2 T 4$ & $\mathrm{P} 1 \mathrm{n}=2 \mathrm{~T} 4$ \\
\hline & & & $P 2 n=3 T 4$ & $P 2 n=2 T 5$ & $P 2 n=3 T 5$ \\
\hline & & & P3 n=3 T5 & P3 n=3 T5 & P3 n=4 T6 \\
\hline & & & P4 n=3 T6 & $P 4 n=3 T 6$ & P4 n=3 T6 \\
\hline \multirow{3}{*}{ C. calcitrans } & \multirow{3}{*}{ V. tapetis } & \multirow{3}{*}{ BRD- } & P1 n=3 T1 & & \\
\hline & & & $P 2 n=3 T 2$ & & \\
\hline & & & P3 n=3 T3 & & \\
\hline \multirow{4}{*}{ C. calcitrans } & \multirow{4}{*}{ V. tapetis } & \multirow{4}{*}{ BRD+ } & & $\begin{array}{l}P 1 n=3 \text { T1 } \\
P 2 \text { n=3 T2 }\end{array}$ & $\mathrm{P} 1 \mathrm{n}=3 \mathrm{~T} 1$ \\
\hline & & & & P3 n=4 T2 & $P 2 n=3 T 2$ \\
\hline & & & & P4 n=3 T3 & P3 n=4 T3 \\
\hline & & & & P5 n=3 T3 & \\
\hline \multirow{4}{*}{ T-Iso } & \multirow{4}{*}{ FSW } & \multirow{4}{*}{ Control } & $P 1 n=3 T 13$ & $P 1 n=2 T 13$ & \\
\hline & & & $P 2 n=3 T 14$ & P2 n=3 T14 & P1 n=3 T14 \\
\hline & & & P3 n=3 T14 & P3 n=4 T15 & $P 2 n=3 T 15$ \\
\hline & & & P4 n=3 T15 & & \\
\hline \multirow{4}{*}{ T-Iso } & \multirow{4}{*}{ V. tapetis } & & $P 1 n=3 T 10$ & & \\
\hline & & & $P 2 n=3 T 10$ & $P 1 n=2 T 10$ & \\
\hline & & & P3 n=5 T11 & $P 2 n=2 T 10$ & \\
\hline & & & $P 4 n=3 T 12$ & & \\
\hline \multirow{2}{*}{ T-Iso } & \multirow{2}{*}{ V. tapetis } & & & $P 1 n=3 T 11$ & $P 1 n=5 T 10$ \\
\hline & & & & $P 2 n=3 T 12$ & $P 2 n=4 T 11$ \\
\hline
\end{tabular}


Table 2: Percent composition of the main long-chain polyunsaturated fatty acids in total lipids of T-Isochrysis aff. galbana, clone Tahitian (T-Iso) and Chaetoceros calcitrans (C. calcitrans) and neutral lipids of the digestive gland of control clams (DG) at $2 \mathrm{dpi}$. Values are mean \pm standard deviations, expressed as percentage of total fatty acids ( $n=3$ samples).

\begin{tabular}{|c|c|c|c|c|}
\hline Fatty acid & & sae & & $\mathrm{DG}$ \\
\hline & C. calcitrans & T-Iso & C. calcitrans & T-Iso \\
\hline $20: 4 n-6$ & $9.2 \pm 3.3$ & $3.1 \pm 0.7$ & $4.6 \pm 0.6$ & $1.2 \pm 0.2$ \\
\hline $20: 5 n-3$ & $14.0 \pm 1.4$ & $0.4 \pm 0.1$ & $12.6 \pm 2.1$ & $2.0 \pm 1.3$ \\
\hline $22: 6 n-3$ & $1.3 \pm 0.1$ & $8.4 \pm 0.4$ & $5.1 \pm 1.0$ & $14.1 \pm 1.4$ \\
\hline
\end{tabular}


Table 3: Percent composition of the main long-chain polyunsaturated fatty acids in polar lipids of clam mantle collected at $7 \mathrm{dpi}$. Clams were fed Chaetoceros calcitrans or TIsochrysis aff. galbana, clone Tahitian (T-Iso) and injected with filtered seawater (control) or Vibrio tapetis. Clams injected with V. tapetis were either BRD- (no clinical sign of infection) or BRD+ (visible brown ring). Values are mean \pm standard deviations, expressed as percentage of total fatty acids.

\begin{tabular}{|c|c|c|c|c|c|}
\hline \multirow[t]{2}{*}{ Fatty acid } & \multicolumn{2}{|c|}{ C. calcitrans } & \multicolumn{2}{|r|}{ T-Iso } & \multirow[b]{2}{*}{ BRD+ } \\
\hline & Control & BRD+ & Control & BRD & \\
\hline $20: 4 n-6$ & $5.4 \pm 0.5$ & $5.4 \pm 0.4$ & $5.0 \pm 0.4$ & $5.0 \pm 0.8$ & $4.9 \pm 0.2$ \\
\hline $20: 5 n-3$ & $7.4 \pm 0.5$ & $7.2 \pm 0.4$ & $5.7 \pm 0.3$ & $5.3 \pm 0.5$ & $5.8 \pm 0.1$ \\
\hline $22: 6 n-3$ & $19.5 \pm 0.8$ & $19.8 \pm 0.6$ & $21.6 \pm 1.5$ & $20.6 \pm 1.0$ & $21.0 \pm 0.7$ \\
\hline Unsaturation index & $277 \pm 3.4$ & $274 \pm 4.6$ & $282 \pm 8.6$ & $277 \pm 0.7$ & $282 \pm 4.2$ \\
\hline
\end{tabular}


Table 4: Summary of PERMANOVA conducted on different sampling times (significant effects are in bold).

\begin{tabular}{|c|c|c|c|c|}
\hline \multirow{2}{*}{ Times } & \multirow{2}{*}{ Explanatory variables } & \multicolumn{3}{|c|}{ PERMANOVA statistics } \\
\hline & & $r^{2}$ & $\mathrm{~F}$ & $\mathrm{p}$-value \\
\hline \multirow{3}{*}{2,7 and $30 \mathrm{dpi}$} & Diet & 0.01 & 0.54 & 0.64 \\
\hline & Treatment & 0.30 & 2.19 & 0.03 \\
\hline & Diet $\mathrm{x}$ Treatment & 0.20 & 1.78 & 0.09 \\
\hline \multirow{3}{*}{2 and $7 \mathrm{dpi}$} & Diet & 0.04 & 1.7 & 0.16 \\
\hline & Treatment & 0.36 & 3.89 & $<0.01$ \\
\hline & Diet $x$ Treatment & 0.28 & 4.08 & $<0.01$ \\
\hline \multirow{3}{*}{$2 \mathrm{dpi}$} & Diet & 0.03 & 0.65 & 0.53 \\
\hline & Injection x BRD status & 0.29 & 5.8 & 0.01 \\
\hline & Diet $\mathrm{x}$ Injection $\mathrm{x}$ BRD status & 0.14 & 2.86 & 0.07 \\
\hline \multirow{3}{*}{$7 \mathrm{dpi}$} & Diet & 0.07 & 1.24 & 0.32 \\
\hline & Injection x BRD status & 0.3 & 2.68 & 0.03 \\
\hline & Diet $\mathrm{x}$ Injection $\mathrm{x}$ BRD status & 0.02 & 0.36 & 0.81 \\
\hline \multirow{3}{*}{$30 \mathrm{dpi}$} & Diet & 0.06 & 0.51 & 0.66 \\
\hline & Injection $\times$ BRD status & 0.03 & 0.23 & 0.92 \\
\hline & Diet $\mathrm{x}$ Injection $\mathrm{x}$ BRD status & 0.06 & 0.52 & 0.63 \\
\hline
\end{tabular}




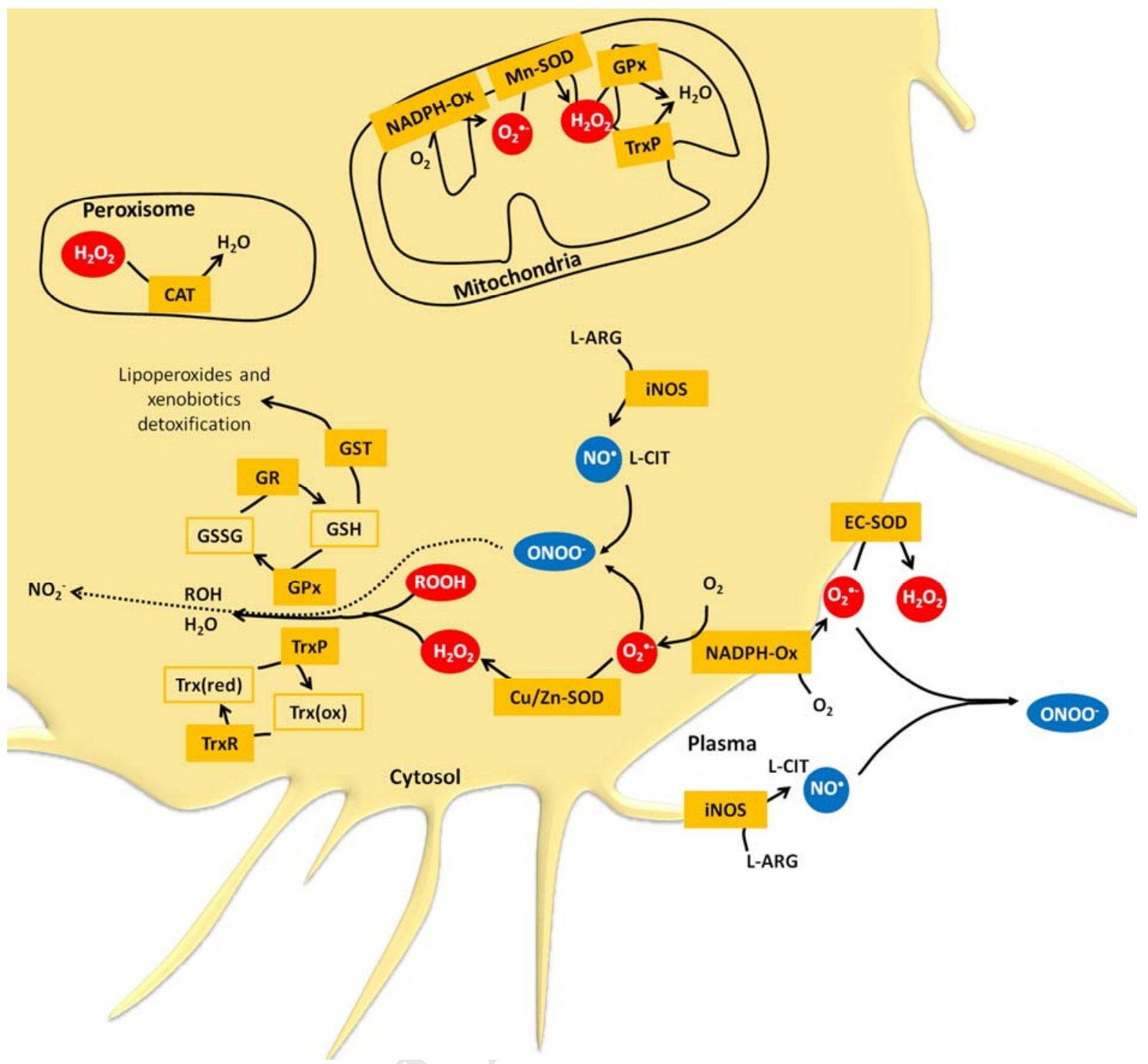




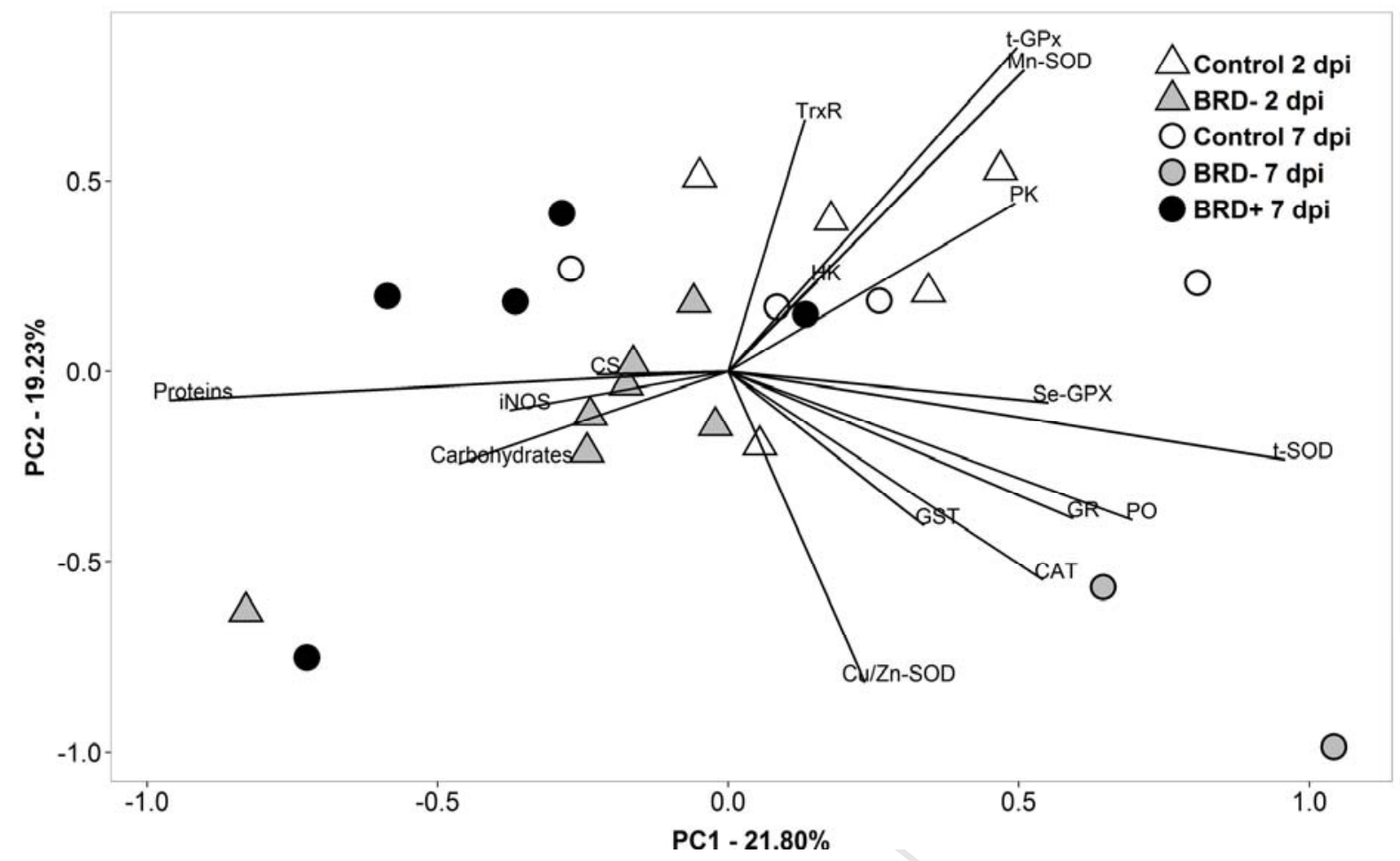



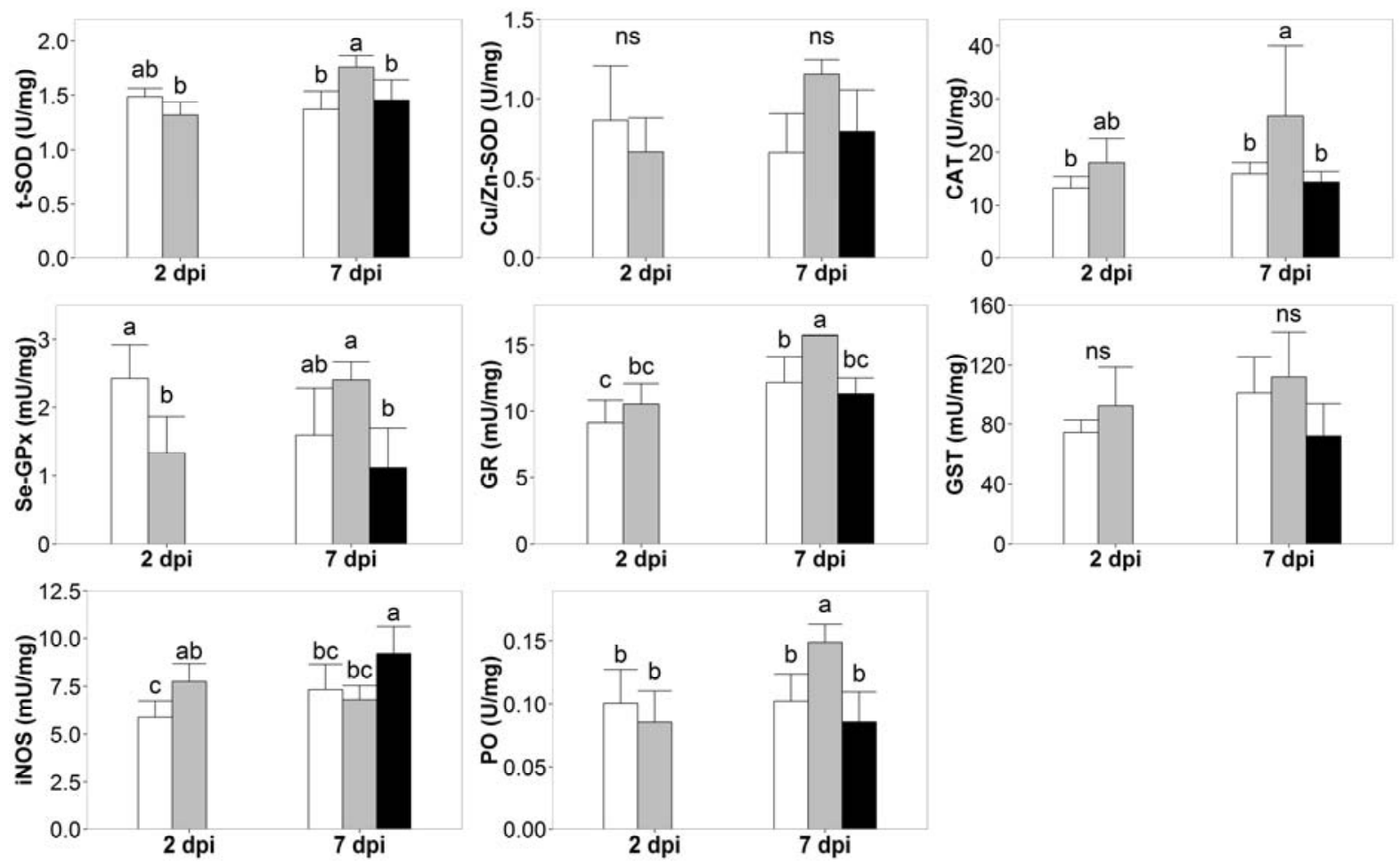